\title{
Phytosociological study of the forest vegetation of Kyiv urban area (Ukraine)
}

\author{
Igor V. Goncharenko' (i) \& Halina M. Yatsenko ${ }^{1}$ (i)
}

Key words: forest vegetation, syntaxonomy, DRSA algorithm, classification of vegetation, Kyiv, Central Ukraine.

Ključne besede: gozdna vegetacija, sintaksonomija, DRSA algoritem, klasifikacija vegetacije, Kijev, osrednja Ukrajina.

Received: 22. 11. 2018

Revision received: 9. 7. 2019

Accepted: 17. 7. 2019

\begin{abstract}
The study presents a floristic-sociological classification of the forest vegetation of Kyiv urban area. We identified 18 syntaxa within 7 classes, 7 orders, 8 alliances, and 3 new associations were allocated (Aristolochio clematitis-Populetum nigrae, Galio aparines-Aceretum negundi, Dryopterido carthusianae-Pinetum sylvestris). We analyzed vegetation data using quantitative approaches of ordination and phytoindication. Considering many relevés of transitional nature in the collected data on urban forests, the clustering algorithm of DRSA (Distance-Ranked Sorting Algorithm) was applied to classify vegetation matrix. Large-scale comparative floristic analysis of syntaxa from different regions and countries have been conducted and summarized in differentiating tables.

Izvleček

Raziskava predstavlja floristično-sociološko klasifikacijo gozdne vegetacije na urbanem območju Kijeva. Ugotovili smo 18 sintaksonov, ki jih uvrščamo v 7 razredov, 7 redov, 8 zvez in tri nove asociacije (Aristolochio clematitis-Populetum nigrae, Galio aparines-Aceretum negundi, Dryopterido carthusianae-Pinetum sylvestris). Vegetacijske podatke smo analizirali s kvantitativnim pristopom z ordinacijo in fitoindikacijo. Zaradi številnih popisov prehodnih tipov, narejenih $\mathrm{v}$ urbanih gozdovih, smo za klasifikacijo vegetacijske matrike uporabili klastrski algoritem DRSA (Distance-Ranked Sorting Algorithm). V primerjalnih tabelah smo predstavili primerjalno floristično analizo sintaksonov iz različnih območij in držav.
\end{abstract}




\section{Introduction}

The forest vegetation of Kyiv urban area consists of three types: semi-natural forests that are remnants of the Dnieper prehistoric forested area, artificial plantations and spontaneous forest vegetation alternating each other on many sites. Kyiv region is located near the border of two natural zones - Forest and Forest-Steppe. Specific location determines the diversity of habitats. Climate of this region is warm-summer humid continental. The northern and eastern parts are covered with pine and mixed (oakpine) forests. Broadleaved (oak-hornbeam) forests are mainly concentrated in the southern and western parts of the region. Riparian (poplar and alder) forests mainly develop in the floodplain of the Dnieper River.

Until the 80s, vegetation was studied in Ukraine using the dominant classification approach, which led to the impossibility of comparing classification schemes with the western ones, where the Braun-Blanquet approach was used. Currently, the knowledge on forest vegetation according to this approach remains incomplete. Early publications (Povarnitsyn \& Shendrikov 1957, Lyubchenko 1983, Lyubchenko \& Padun 1985, Padun 1985a, Padun $1985 \mathrm{~b}$ ) are of historical importance because of the dominant classification approach used in them and since the vegetation in Kyiv urban area had greatly changed from that time especially in recent decades due to the growth of the capital's population. There are recent publications (Didukh \& Chumak 1992, Lyubchenko \& Vyrchenko 2007, Yakubenko \& Grigora 2007, Onyshchenko 2011, Onyshchenko 2013a, Onyshchenko 2013b, Kozyr 2013), but the synthesis of this data is still necessary.

In this study, we aim to provide a vegetation classification and phytosociological characterization of the main types of forest vegetation of Kyiv urban area, including semi-natural and anthropogenous forests. We will also search for environmental drivers that influence the differentiation of studied vegetation using the phytoindication method. It will be shown that the syntaxa differ significantly in the shares of species of different classes of vegetation and their phytosociological structure will be evaluated and involved to establish the specificity of the floristic composition of syntaxa and assess the degree of their anthropogenic transformation in urban conditions.

\section{Material and methods}

The present study is based on the relevé data (832 relevés) collected by the authors from 2013 to 2016 in Kyiv and suburbs. Vegetation was sampled using $100 \mathrm{~m}^{2}$ plots. Turboveg software (Hennekens \& Schaminée 2001) was used to store and manage relevé data. Species taxonomy was unified in accordance with the Ukrainian checklist (Mosyakin \& Fedoronchuk 1999) and with some corrections regarding the latest data from online taxonomic resources (http:// www.catalogueoflife.org, http://www.theplantlist.org).

Vegetation classification was conducted in two steps. Firstly, the relevé dataset was classified using the DRSA algorithm (Goncharenko 2015). It is non-parametric and robust due to ranked distances and belongs to a family of the k-nearest neighbor's approaches (Cover \& Hart 1967). Secondly, species were classified and sorted by their fidelities (Bruelheide 2000, Chytrý \& Tichý 2003). Fidelities were calculated using the Ochiai index (De Cáceres et al. 2008) and 50\% threshold was chosen for differential species. Syntaxa were considered and identified regarding different sources of reliable syntaxonomical information (Schubert et al. 2001, Matuszkiewicz 2007, Jarolimek \& Sibik 2008, Onyshchenko 2009, Chytrý et al. 2013, Mucina et al. 2016). Syntaxonomic nomenclature follows the Code of Phytosociological Nomenclature (ICPN), $3^{\text {rd }}$ edition (Weber et al. 2000).

Synoptic table with species constancies is provided in Table 1 and the reordered relevé matrix (Table S1) is placed in the electronic supplement of the article.

We applied DCA ordination (Hill \& Gauch 1980), as this method is advisable in the case of high heterogeneity of the data (Leps \& Smilauer 2003). Ordination were performed using R software (https://cran.r-project.org) with the decorana function from the vegan package (Oksanen et al. 2018). To understand the nature of the axes of unconstrained ordination in terms of environmental factors, we added 10 supplementary (passive) phytoindicational variables. For eight of them, we chose the Didukh's ecological scales (Didukh 2011). To assess anthropogenic impact, we also applied the hemeroby (Frank \& Klotz 1990) and the naturalness (Borhidi 1995) scales. Phytoindicational scores were calculated for each relevé as weighted averages regarding species abundances. These data were involved in the assessment of the correlation with the axes of the unconstrained ordination, and were also aggregated to obtain the ecological characteristics of syntaxa taking into account the relevé-to-cluster membership.

\section{Results and discussion}

Given the analyzed relevé dataset on forest vegetation of Kyiv urban area, we identified 18 syntaxa within 7 classes, 7 orders, 8 alliances, and 18 syntaxa including associations and subordinate units. The numbers in the syntaxonomic scheme correspond to the numbers also used in the tables and figures further in the text. 


\section{Syntaxonomic scheme of vegetation}

SALICETEA PURPUREAE Moor 1958 (syn. Salici purpureaePopuletea nigrae Rivas-Mart. et Cantó ex Rivas-Mart. et al. 1991) Salicetalia purpureae Moor 1958

Salicion albae Soó 1951 (syn. Populion albae Tx. 1931, Populion nigrae Schnitzler 1988)

1. Aristolochio clematitis-Populetum nigrae ass. nov. hoc loco (Salici albae-Populetum nigrae sensu auct. Ukr. non (Tx. 1931) Meyer-Drees 1936)

ROBINIETEA Jurko ex Hadač et Sofron 1980

Chelidonio-Robinietalia Jurko ex Hadač et Sofron 1980 Aegopodio podagrariae-Sambucion nigrae Chytrý 2013 (Chelidonio-Acerion negundi L. et A. Ishbirdin 1989 nom. inval., ICPN, art. 1)

Galio aparines-Aceretum negundi ass. nov. hoc loco (Chelidonio-Aceretum negundi Ishbirdina et Ishbirdin 1989 nom. inval., ICPN, art. 1)

2. Galio aparines-Aceretum negundi var. Aristolochia clematitis

3. Galio aparines-Aceretum negundi typicum

Chelidonio majoris-Robinion pseudoacaciae Hadač et Sofron ex Vítková in Chytrý 2013

Balloto nigrae-Robinietum pseudoacaciae Jurko 1963

4. Balloto nigrae-Robinietum var. Acer tataricum

5. Balloto nigrae-Robinietum typicum

ALNO GLUTINOSAE-POPULETEA ALBAE P. Fukarek et Fabijanić 1968

Alno-Fraxinetalia excelsioris Passarge 1968

Alnion incanae Pawłowski et al. 1928 (syn. Alno-Ulmion minoris Br.-Bl. et Tx. 1943, Alno-Padion Knapp 1942)

6. Carici remotae-Fraxinetum excelsioris Koch ex Faber 1936

CARPINO-FAGETEA SYLVATICAE Jakucs ex Passarge

1968 (syn. Querco-Fagetea Br.-Bl. et Vlieger in Vlieger 1937)

Carpinetalia betuli P. Fukarek 1968 (Fagetalia sylvaticae sensu auct. Ukr.)

Carpinion betuli Issler 1931

Galeobdoloni luteae-Carpinetum betuli Shevchyk, Bakalyna et V. Solomakha 1996

7. Galeobdoloni-Carpinetum var. Acer campestre

8. Galeobdoloni-Carpinetum var. Prunus avium

9. Galeobdoloni-Carpinetum var. Mercurialis perennis

10. Galeobdoloni-Carpinetum var. Carex pilosa

11. Galeobdoloni-Carpinetum typicum

Galeobdoloni luteae-Carpinetum betuli subass. impatientosum parviflorae Goncharenko, Ignatjuk et Shelyag-Sosonko 2013

12. com. Acer platanoides+Lapsana communis
QUERCETEA ROBORI-PETRAEAE Br.-Bl. et Tx. ex Oberd. 1957

Quercetalia roboris $\mathrm{R}$. Tx. 1931

Vaccinio myrtilli-Quercion roboris Bulokhov et Solomeshch 2003

Dryopterido carthusianae-Pinetum sylvestris ass. nov. hoc loco (Pteridio-Pinetum sylvestris Andrienko 1986 nom. invalid., ICPN, art. 2b, 5)

13. Dryopterido-Pinetum sylvestris var. Cardamine impatiens

14. Dryopterido-Pinetum sylvestris var. Fragaria vesca

15. Dryopterido-Pinetum sylvestris var. Carex ericetorum

16. Dryopterido-Pinetum sylvestris typicum

VACCINIO-PICEETEA Br.-Bl. in Br.-Bl. et al. 1939

Pinetalia sylvestris Oberd. 1957

Dicrano-Pinion (Libbert 1932) Matuszkiewicz 1962 nom. cons. propos. (syn. Pino-Quercion MedweckaKornaś et al. in Szafer 1959)

17. Chamaecytiso zingeri-Pinetum sylvestris Vorobyov, Balaschov et V. Solomakha 1997

\section{QUERCETEA PUBESCENTIS Doing-Kraft ex Scamoni et} Passarge 1959

Quercetalia pubescenti-petraeae Klika 1933

Convallario majalis-Quercion roboris Shevchyk et V. Solomakha 1996

18. Polygonatoodorati-Quercetum roboris (Shevchyk et V. Solomakha 1996) Goncharenko et Yatsenko nom. nov. hoc loco (Convallario majalis-Quercetum roboris sensu Shevchyk et V. Solomakha 1996, ICPN, art. 31)

\section{Numerical analysis of phytocoenotic clusters}

Figure 1 shows the tree diagram of cluster analysis of the studied forest syntaxa taking into account species constancies in the columns of the synoptic table. Numerical study of the syntaxa was fulfilled using the flexible-beta algorithm with beta $=-0.25$ (Lance \& Williams 1966).

There are apparently 6 groups (Figure 1, gray-painted groups). The first group consists of the only cluster \#1 of the riparian type which is distinctly separated from the rest. The second group is formed by the syntaxa (2-5) of anthropogenic vegetation. There is some discrepancy between the dendrogram and the syntaxonomic scheme in the third group (clusters 12-17), which combines syntaxa from Vaccinio-Piceetea (17), Quercetea robori-petraeae (13-16) and one "community" (12). Study region is located outside the main distribution range of mentioned classes, and communities of these classes are not typical 


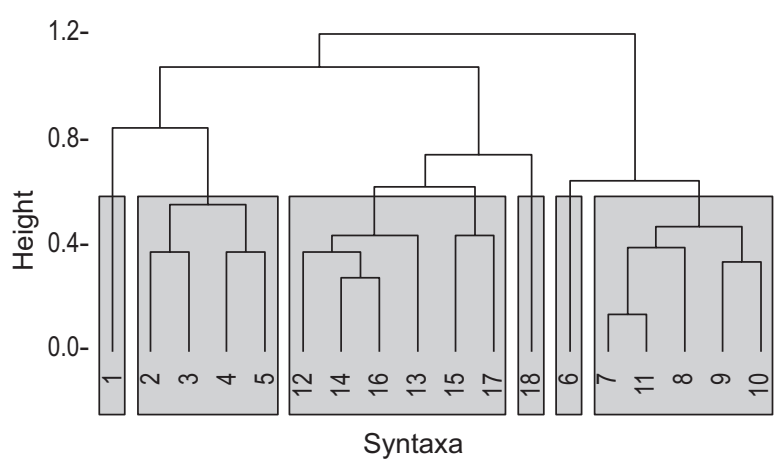

Figure 1: Hierarchical cluster analysis of the syntaxa of forest vegetation of Kyiv urban area. Numbers in the dendrogram correspond to the numbers in the syntaxonomic scheme.

Slika 1: Hierarhična klastrska analiza sintaksonov gozdne vegetacije urbanega območja Kijeva. Številke v dendrogramu so enake kot številke v sintaksonomskem seznamu.

here. Cluster 18 (from Quercetea pubescenti-petraeae) is very close to third group as well.

Table 2 summarized the averaged values of the Ochiai coefficient in pairwise comparison of relevés within and between phytocoenotic clusters.

Inter-cluster similarity analysis focuses on two goals: validation of partitioning and interpretation of syntaxa of higher ranks. The higher the diagonal values of the matrix above, the greater the density of clusters, and the share of species of higher constancies. As can be seen from Table 2, all phytocoenotic clusters have the maximal value in the diagonal, and for most clusters the difference between diagonal and any of non-diagonal values is high. This evidences in favor of the distinguishability of clusters using distance-based criterion.

The «cluster validation" term is commonly used for a procedure of evaluating the goodness of partitioning. In our case, we applied similar approach to assess the reliability of different clusters. This technique is not a reason for removing some clusters, but it allows recognizing some clusters as "good» or "weak». We used different metrics - inner validation criteria and floristic ones. The $\mathrm{R}$ repository (http://cran.r-project.org/web/packages) provides many specialized packages for the distancebased (inner) assessment, for example clValid (Brock et al. 2008), Nbclust (Charrad et al. 2014). The mathematical basis is well described (Halkidi et al. 2001, Rendón et al. 2011). In addition to the Silhouette statistics, we added the partitioning quality index, PQI (Goncharenko 2016).

Quality assessment would be incomplete without floristic criteria (Botta-Dukát \& Borhidi 1999, Chytrý et al. 2002, De Cáceres et al. 2008, De Cáceres \& Legendre 2009). Therefore, we added five floristic measures:

- the averages of constancies (avg_k), specifities (avg_x), and fidelities (avg_kx) of species;

- the homotoneity coefficient, Ht (Moravec 1973), which expresses the share of species with more than $40 \%$ constancy in the cluster;

- the sharpness index (Chytrý \& Tichý 2003).

Table 2: Averaged similarities of relevés within and between phytocoenotic clusters.

Tabela 2: Povprečna podobnost popisov znotraj in med vegetacijskimi klastri.

\begin{tabular}{cccccccccccccccccccc}
\hline cluster & 1 & 2 & 3 & 4 & 5 & 6 & 7 & 8 & 9 & 10 & 11 & 12 & 13 & 14 & 15 & 16 & 17 & 18 \\
\hline 1 & 0.38 & 0.31 & 0.23 & 0.16 & 0.15 & 0.09 & 0.12 & 0.14 & 0.1 & 0.09 & 0.11 & 0.17 & 0.18 & 0.17 & 0.17 & 0.17 & 0.13 & 0.13 \\
2 & $*$ & 0.45 & 0.4 & 0.32 & 0.29 & 0.17 & 0.22 & 0.25 & 0.2 & 0.17 & 0.2 & 0.25 & 0.25 & 0.24 & 0.23 & 0.24 & 0.13 & 0.12 \\
3 & $*$ & $*$ & 0.48 & 0.41 & 0.39 & 0.18 & 0.25 & 0.26 & 0.24 & 0.2 & 0.23 & 0.28 & 0.26 & 0.23 & 0.23 & 0.25 & 0.12 & 0.11 \\
4 & & $*$ & $* *$ & 0.7 & 0.53 & 0.17 & 0.29 & 0.31 & 0.28 & 0.23 & 0.29 & 0.34 & 0.26 & 0.25 & 0.2 & 0.3 & 0.12 & 0.12 \\
5 & & $*$ & $*$ & $* *$ & 0.54 & 0.25 & 0.32 & 0.37 & 0.38 & 0.33 & 0.33 & 0.35 & 0.29 & 0.27 & 0.23 & 0.32 & 0.13 & 0.13 \\
6 & & & & & $*$ & 0.42 & 0.25 & 0.27 & 0.34 & 0.31 & 0.28 & 0.23 & 0.2 & 0.2 & 0.24 & 0.23 & 0.12 & 0.09 \\
7 & & $*$ & $*$ & $*$ & $*$ & $*$ & 0.47 & 0.35 & 0.35 & 0.37 & 0.42 & 0.27 & 0.24 & 0.21 & 0.22 & 0.24 & 0.11 & 0.11 \\
8 & & $*$ & $*$ & $*$ & $*$ & $*$ & $*$ & 0.47 & 0.38 & 0.35 & 0.38 & 0.32 & 0.3 & 0.29 & 0.27 & 0.32 & 0.16 & 0.16 \\
9 & & & $*$ & $*$ & $*$ & $*$ & $*$ & $*$ & 0.54 & 0.41 & 0.4 & 0.3 & 0.26 & 0.22 & 0.24 & 0.27 & 0.13 & 0.1 \\
10 & & & & $*$ & $*$ & $*$ & $*$ & $*$ & $* *$ & 0.46 & 0.4 & 0.26 & 0.25 & 0.22 & 0.22 & 0.25 & 0.12 & 0.11 \\
11 & & & $*$ & $*$ & $*$ & $*$ & $* *$ & $*$ & $*$ & $*$ & 0.44 & 0.28 & 0.25 & 0.22 & 0.23 & 0.26 & 0.13 & 0.12 \\
12 & & $*$ & $*$ & $*$ & $*$ & $*$ & $*$ & $*$ & $*$ & $*$ & $*$ & 0.38 & 0.34 & 0.34 & 0.34 & 0.37 & 0.22 & 0.2 \\
13 & $*$ & $*$ & $*$ & $*$ & & $*$ & $*$ & $*$ & $*$ & $*$ & $*$ & 0.51 & 0.44 & 0.39 & 0.41 & 0.29 & 0.3 \\
14 & $*$ & $*$ & $*$ & $*$ & & $*$ & $*$ & $*$ & $*$ & $*$ & $*$ & $* *$ & 0.53 & 0.41 & 0.46 & 0.3 & 0.34 \\
15 & $*$ & $*$ & & $*$ & $*$ & $*$ & $*$ & $*$ & $*$ & $*$ & $*$ & $*$ & $* *$ & 0.53 & 0.44 & 0.33 & 0.26 \\
16 & $*$ & $*$ & $*$ & $*$ & $*$ & $*$ & $*$ & $*$ & $*$ & $*$ & $*$ & $* *$ & $* *$ & $* *$ & 0.49 & 0.3 & 0.27 \\
17 & & & & & & & & & & & & $*$ & $*$ & $*$ & $*$ & $*$ & 0.37 & 0.28 \\
18 & & & & & & & & & & & & & $*$ & $*$ & $*$ & $*$ & $*$ & 0.4 \\
\hline
\end{tabular}

Notes: ID syntaxa correspond to the numbers in the syntaxonomic scheme.

Asterisks in cells - mnemonic codes: $\left.{ }^{* * *}{ }\right\rangle-$ similarity $>0.6$; $\left\langle{ }^{* *} »-\right.$ similarity $>0.4 ;\left\langle{ }^{*} »-\right.$ similarity $>0.2$ 
Table 3 summarizes the results of the quality assessment of phytocoenotic clusters. Since none of methods can be considered comprehensive, the overall assessment was strengthened using a balanced criterion. Firstly, all indices were ranked in each column (by measure), than averages of ranks were calculated in each row (by cluster) and normalized («avg_rank» column).

Table 3: Quality assessment of phytocoenotic clusters using inner and floristic measures.

Tabela 3: Kvalitativne ocene vegetacijskih klastrov z uporabo notranjih in florističnih ocen.

\begin{tabular}{|c|c|c|c|c|c|c|c|c|}
\hline cluster & $P Q I$ & silh & $H t$ & Sharpness & $\operatorname{avg} k$ & $\operatorname{avg} x$ & avg_kx & \\
\hline 1 & 0.18 & 0.07 & 0.80 & 57.19 & 41.90 & 33.60 & 33.10 & 0.66 \\
\hline 2 & 0.11 & 0.07 & 0.86 & 29.27 & 45.50 & 8.90 & & 0.43 \\
\hline 3 & 0.15 & 0.06 & 0.82 & 28.95 & & 12.00 & & 0.50 \\
\hline 4 & 0.24 & 0.37 & 1.02 & 16.09 & 69.60 & 2.40 & 12.20 & 0.56 \\
\hline 5 & 0.02 & 0.01 & 0.83 & 19.28 & 53.70 & 5.40 & 15.50 & 0.28 \\
\hline 6 & 0.19 & 0.09 & 0.90 & 41.70 & 42.00 & 16.20 & 18.80 & 0.62 \\
\hline 7 & 0.11 & 0.05 & 1.04 & 37.95 & 47.40 & 18.90 & 27.50 & 0.66 \\
\hline 8 & 0.19 & 0.03 & 0.82 & & & 17.10 & & 0.58 \\
\hline 9 & 0.24 & 0.19 & 0.87 & & & 4.10 & & 0.52 \\
\hline 10 & 0.11 & 0.04 & 0.62 & 20.08 & 51.80 & 6.50 & 17.10 & 0.31 \\
\hline 11 & 0.05 & -0.04 & 0.90 & 32.16 & 45.40 & 15.00 & 24.30 & 0.45 \\
\hline 12 & 0.03 & -0.10 & 0.66 & 21.68 & 42.60 & 7.50 & 16.10 & 0.16 \\
\hline 13 & 0.14 & 0.11 & 0.88 & 20.25 & 53.10 & 5.10 & 15.10 & 0.47 \\
\hline 14 & 0.13 & 0.10 & 0.86 & 26.97 & 50.60 & 9.40 & 20.60 & 0.53 \\
\hline 15 & 0.17 & 0.15 & 0.88 & 28.52 & 51.40 & 11.00 & 21.60 & 0.63 \\
\hline 16 & 0.06 & 0.00 & 0.91 & 35.23 & 47.10 & 22.70 & 31.30 & 0.59 \\
\hline 17 & 0.11 & 0.01 & 0.74 & 35.69 & 44.30 & 20.50 & 25.80 & 0.45 \\
\hline 18 & 0.15 & 0.06 & 0.80 & 48.89 & 42.20 & 25.20 & 29.10 & 0.60 \\
\hline
\end{tabular}

As seen from Table 3, only clusters 11 and 12 show negative Silhouette values, however they have positive values of PQI which is also distance-based criterion. Cluster densities can be judged by $H t$ and $a v g \_k$ scores and all clusters are quite homogeneous. Regarding values in avg_rank column, a balanced measure, clusters $1,7,15$ are the strongest, while clusters 5, 10 and 12 have the smallest values.

\section{Ordination of vegetation}

Figure 2 shows the plot of DCA ordination in a space of the first two ordination axes with environmental variables projected by the vegan::envfit function (Oksanen et al. 2018).

Clusters 1, 17, 18 are the most different from the others and occupy the distant right position along the first axis which is associated with $L c$ and $K n$. This is consistent with the fact that they are representatives of the vegetation types distributed mainly in subcontinental regions. In contrast, clusters 7-11 of the Carpino-Fagetea class are located in the leftmost position along the first axis. The first axis is strongly correlated with $L c$ (this factor is critical in forest vegetation) and these nemoral communities develop in shady sites (in the opposite direction from the Lc arrow). Relevés from clusters 2 and 3 which represent anthropogenous urban forests have scores related mainly to the second axis, and variables that are correlated with anthropogenic load, $H m$ and $N v$, also demonstrate greater contribution to the second axis of ordination.

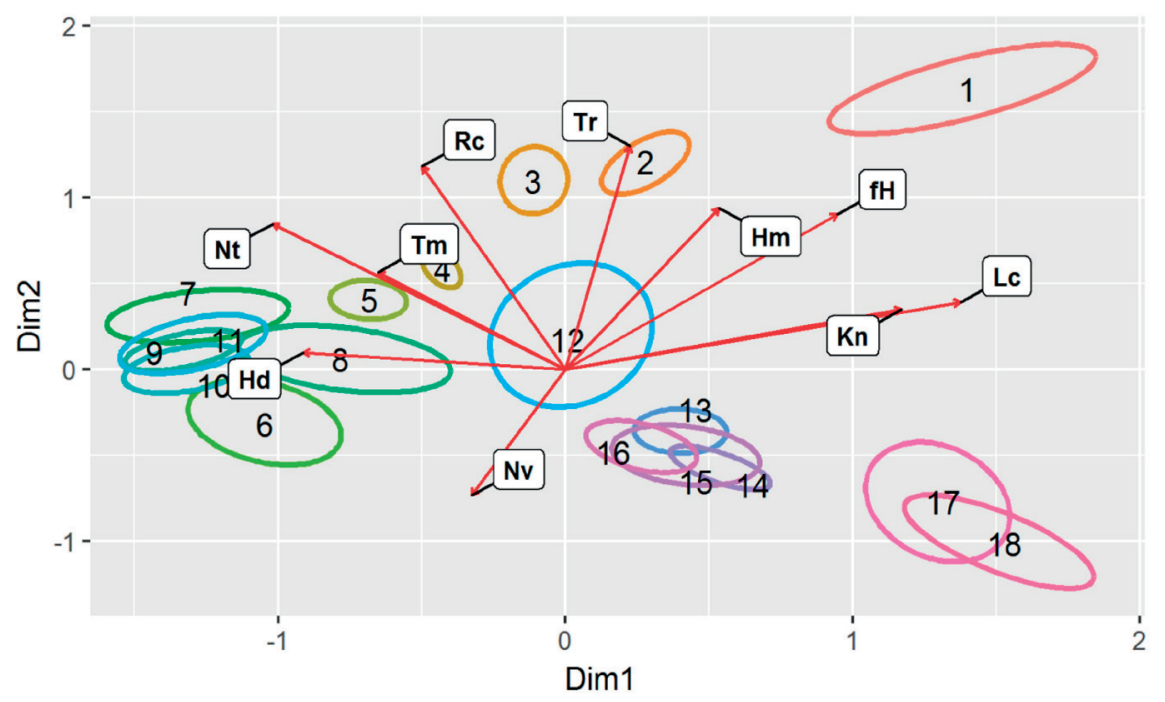

Figure 2: DCA ordination diagram with supplementary (passive) environmental variables. Abbreviations of environmental variables: $L c$ - light value, $N t$ - nitrogen value, $\operatorname{Tr}$ - total salt regime, $f H$ - variability of moisture, $R c$ - soil reaction value, $K n-$ continentality value, $\mathrm{Hm}$ - hemeroby index, $H d$ - moisture value, $T m$ - temperature value, $N v$ - naturalness value.

Slika 2: DCA ordinacijski diagram $s$ pasivno prikazanimi okoljskimi spremenljivkami. Okrajšave okoljskih spremenljivk: $L c-$ svetloba, $N t$ - dušik, $T r$ - slanost, $f H$ - spremenljivost vlažnosti, $R c$ - reakcija tal, $K n$ - kontinentalnost, $\mathrm{Hm}$ - indeks hemerobije, $H d$ - vlažnost, $T m$ - temperatura, $\mathrm{Nv}$ - naravnost. 


\section{Phytosociological structure of species composition of syntaxa}

Synanthropic species are common in the studied syntaxa due to urban conditions and this complicates syntaxonomic decisions. In such a case, the phytosociological spectrum becomes a reliable suggesting tool. The term "phytosociological spectrum" means a method of measuring and comparing the proportions of diagnostic species of different classes of vegetation in the species composition of each syntaxon (Goncharenko et al. 2013b). It is also a method of understanding the ecological specificity of communities, as the proportions of phytosociological spectrum indicate environmental conditions under which the certain types of communities develop.

Table 4 shows the proportions of species of different classes of vegetation in each syntaxon. For species-toclass classification, we have chosen the EuroVegChecklist as a basis (Mucina et al. 2016). To measure the degree of transitiveness of syntaxa (the uncertainty of placement in only one class of vegetation) we calculated the differences in shares between the first and the second classes of phytosociological spectrum ("diff" column). Syntaxon should be considered ecotonic in the case of low values in this column.

Table 4: Phytosociological spectra of the syntaxa of forest vegetation. Only classes with a share of species greater than $0.05(5 \%)$ in at least one syntaxon are presented in the table.

Tabela 4: Fitocenološki spekter sintaksonov gozdne vegetacije. $\mathrm{V}$ tabeli so prikazani samo razredi $\mathrm{z}$ deležem vrst $\mathrm{v}$ vsaj enem sintaksonu, večjim od 0,05 (5\%).

\begin{tabular}{cccccccccccc}
\hline ID & diff & BRA & EPI & FAG & GER & MOL & POP & QUE & ROB \\
syntaxon & & & & & & & & \\
\hline 1 & 0.02 & - & 0.24 & - & - & 0.23 & 0.26 & - & 0.09 \\
2 & 0.01 & - & 0.32 & 0.13 & - & - & 0.33 & - & 0.15 \\
3 & 0.01 & - & 0.32 & 0.10 & - & - & 0.33 & - & 0.25 \\
4 & 0.05 & - & 0.33 & 0.17 & - & - & 0.22 & - & 0.28 \\
5 & 0.03 & - & 0.28 & 0.18 & - & - & 0.24 & - & 0.31 \\
6 & 0.04 & - & 0.19 & 0.32 & - & - & 0.36 & - & 0.10 \\
7 & 0.29 & - & 0.13 & 0.52 & - & - & 0.23 & - & 0.07 \\
8 & 0.10 & - & 0.15 & 0.38 & - & - & 0.28 & - & 0.10 \\
9 & 0.15 & - & 0.17 & 0.43 & - & - & 0.28 & - & 0.13 \\
10 & 0.43 & - & 0.13 & 0.65 & - & - & 0.22 & - & - \\
11 & 0.31 & - & 0.14 & 0.54 & - & - & 0.23 & - & 0.09 \\
12 & 0.05 & - & 0.32 & 0.25 & - & - & 0.27 & - & 0.17 \\
13 & 0.02 & 0.14 & 0.19 & 0.24 & - & - & 0.22 & - & - \\
14 & 0.01 & 0.10 & 0.17 & 0.24 & - & - & 0.25 & - & - \\
15 & 0.02 & 0.09 & 0.27 & 0.29 & - & - & 0.27 & - & - \\
16 & 0.04 & - & 0.23 & 0.24 & - & - & 0.28 & - & 0.15 \\
17 & 0.03 & - & 0.19 & 0.18 & - & - & 0.17 & 0.22 & - \\
18 & 0.05 & 0.17 & - & 0.14 & 0.22 & - & - & 0.15 & - \\
\hline
\end{tabular}

Abbreviations of classes according to Mucina et al. (2016)
As can be seen from Table 4, species of some classes are classified in the majority of compared syntaxa. For example, Carpino-Fagetea ("FAG" column) which is a zonal type of forest vegetation in Kyiv region. Also, almost all syntaxa contain a significant participation of Epilobietea angustifolii species ranging from 0.13 to 0.33 , as a result of recreational and other anthropogenic pressures. Species of other classes ("GER", "MOL" etc.) play differentiating role in the studied forest vegetation. For example, in syntaxon \#1 which is the riparian forest type the participation of species of the Molinio-Arrhenatheretea class is associated with the formation in the floodplains, where meadows usually develop. Species of the class Trifolio-Geranietea constitute up to $0.22(22 \%)$ of the species composition in syntaxon \#18, which is caused by xeric conditions and sparse tree layer in these forest communities.

\section{Phytocoenotic characterization and description of new syntaxa}

In this section, we present the phytocoenotic characteristic of syntaxa taking into account differentiating species and preferred habitats, as well as the results of phytoindicational and phytosociological assessment from previous sections of the article and aggregated header data obtained for relevés of certain clusters of vegetation. In the following text the syntaxa numbers corresponds to the numbers in the syntaxonomic scheme. Dominant (dom.), constant (const.) and differential (diff.) species are listed for each association. For three associations introduced as new ones, the comparative floristic tables with similar syntaxa (including holotypes) are given in order to confirm their distinguishability and establish differentiating species considering broader geographic scope of such analysis. Also for each syntaxon we will list the related syntaxa. The term "related" does not mean that we regard the syntaxa as synonyms in the nomenclatural sense. This implies similarity in species composition and close position in the syntaxonomic scheme. Such lists of related syntaxa are a part of characteristic and may indicate distant syntaxonomic relations with syntaxa placed by authors in other alliances/orders. They are also aimed at identifying a potential distribution range of associations in wider territories than the region of study.

\section{Aristolochio clematitis-Populetum nigrae ass. nova hoc loco}

Dom.: Populus spp. (P. nigra, P. alba, P. tremula), Ulmus laevis, Betula pendula, Pinus sylvestris, Quercus robur Const.: Rubus caesius, Poa pratensis, Rumex thyrsiflorus, Alopecurus pratensis, Tanacetum vulgare, Carex hirta, Dactylis glomerata, Amorpha fruticosa 
Diff:: Aristolochia clematitis, Galium verum, Galium rubioides, Carex praecox, Asparagus officinalis, Filipendula vulgaris, Bromus inermis, Koeleria glauca

EUNIS: G1.1112 Eastern European poplar-willow forests

Related syntaxa. ass. Galio veri-Aristolochietum clematidis Shevchyk et V. Solomakha in Shevchyk et al. 1996, Artemisio dniproicae-Salicetum acutifoliae Shevchyk et V. Solomakha 1996, Euphorbio virgultosae-Amorphetum fruticosae Shevchyk et V. Solomakha 1996

Holotypus: relevé 453 (Table S1); author: H. Yatsenko; date: 26.05.2016; locality: in the central part of the Dolobetsky island of the Dnieper River within the Kyiv city, on sandy soils, in the birch-poplar forest; coordinates: $50.4637^{\circ} \mathrm{N}, 30.5695^{\circ} \mathrm{E}$; total coverage of layers: trees $-70 \%$, shrubs - 30\%, herbs - 90\%. Alopecurus pratensis 2, Aristolochia clematitis 2, Artemisia absinthium 1, Asparagus officinalis + , Berteroa incana 1, Betula pendula 2, Carex praecox 2, Convallaria majalis 1, Crataegus monogyna 1, Dactylis glomerata 1, Erigeron canadensis +, Eryngium planum +, Festuca pratensis 1, Filipendula vulgaris 2, Fraxinus excelsior +, Galium rubioides +, Galium verum 2, Hypericum perforatum +, Myosotis stricta + , Pinus sylvestris + , Plantago lanceolata + ,
Poa pratensis 3, Populus alba 1, Populus nigra 2, Potentilla argentea + , Quercus robur + , Rhinanthus vernalis 1 , Rumex thyrsiflorus 2, Sedum telephium +, Tanacetum vulgare 1, Trifolium montanum 1, Ulmus laevis +, Vincetoxicum hirundinaria 1.

The association combines dry to mesic species-rich poplar riparian forests. Communities occupy elevated areas of floodplains and sandy islands. They mainly occur in the lower courses of larger rivers with powerful alluvial sediments. Most elevated areas of floodplains are not regularly flooded. Under such conditions, trees, especially birch and poplar species (Populus tremula, P. nigra, $P$. alba), are spreading and producing different-age undergrowth. Sparse canopy of trees favors the growth of lightdemanding forest-fringe herbs and the increase of floristic richness (Table 5).

To understand the dualistic nature of mixture of species, we should note that soil moisture in such habitats greatly changes during the year. In summer, dry conditions prevail which leads to the co-occurrence of mesophytes and drought-adapted species in the same communities.

The syntaxonomic position of the association is rather complicated as for most riparian forests in Eastern Europe. To demonstrate the complicated syntaxonomy of

Table 5: Aggregated data of relevés for each phytocoenotic cluster (syntaxon).

Tabela 5: Združeni podatki o popisih za vsak vegetacijski klaster (sintakson).

\begin{tabular}{ccccccccccc} 
syntaxon & $N$ & $R$ & $\Delta R$ & $S$ & $S 20 \%$ & S40\% & cov_tree & cov_shrub cov_herb & years \\
1 & 39 & 29 & $19-40$ & 139 & 37 & 17 & 56 & 11 & 81 & 2016 \\
2 & 22 & 28 & $23-37$ & 112 & 44 & 21 & 67 & 15 & 78 & 2016 \\
3 & 26 & 21 & $16-30$ & 92 & 37 & 18 & 61 & 10 & 91 & 2016 \\
4 & 7 & 17 & $12-20$ & 32 & 69 & 53 & 66 & 25 & 71 & 2015 \\
5 & 21 & 17 & $11-22$ & 61 & 41 & 23 & 78 & 34 & 54 & $2014-2015$ \\
6 & 9 & 22 & $17-28$ & 73 & 62 & 27 & 73 & 23 & 79 & $2013-2016$ \\
7 & 53 & 24 & $18-33$ & 119 & 35 & 21 & 72 & 30 & 70 & $2013-2016$ \\
8 & 64 & 23 & $10-39$ & 130 & 28 & 15 & 74 & 32 & 53 & $2013-2016$ \\
9 & 11 & 19 & $16-25$ & 62 & 44 & 27 & 68 & 23 & 70 & $2014-2015$ \\
10 & 21 & 19 & $13-26$ & 86 & 31 & 14 & 76 & 23 & 50 & $2013-2015$ \\
11 & 55 & 22 & $12-31$ & 116 & 34 & 17 & 74 & 27 & 65 & $2013-2015$ \\
12 & 30 & 27 & $18-42$ & 162 & 27 & 11 & 56 & 23 & 77 & $2013-2016$ \\
13 & 17 & 25 & $21-34$ & 93 & 40 & 24 & 58 & 34 & 66 & $2015-2016$ \\
14 & 36 & 27 & $16-37$ & 109 & 39 & 21 & 47 & 27 & 69 & 2016 \\
15 & 33 & 26 & $18-49$ & 112 & 37 & 21 & 63 & 29 & 72 & 2016 \\
16 & 115 & 24 & $17-34$ & 142 & 30 & 15 & 59 & 29 & 66 & 2016 \\
17 & 35 & 24 & $16-34$ & 145 & 25 & 12 & 52 & 22 & 74 & $2015-2016$ \\
18 & 41 & 26 & $20-36$ & 137 & 35 & 15 & 38 & 22 & 75 & $2015-2016$ \\
\hline
\end{tabular}

Notations: $N$-number of relevés, $R$-average number of species per relevé, $\Delta R$ - min-max range of the number of species in relevés, $S$ - total number of species in species list of the cluster (syntaxon), S20\% - number of species with constancies higher than $20 \%$ (I constancy class) divided by S, S40\% - the same but with stronger 40\% threshold (I - II constancy classes), the measure of the floristic homogeneity of the cluster, cov_tree - average of the total cover of tree layer in relevés, cov_shrub, cov_herb - the same for the shrub and herb layers, years - the range of years of relevés 
eastern riparian forests, below we will give a brief descriptions of some alliances that were described from Eastern Europe and placed even in different classes of vegetation.

- Galio veri-Aristolochion clematidis Shevchyk et V. Solomakha 1996 (Shevchyk et al. 1996 p. 34) - described from Central Ukraine, the Kaniv Nature Reserve, the holotypus of the association is Galio veri-Aristolochietum clematidis; the association was originally included in the Salicetea purpureae class; in the EuroVegChecklist was transferred to the Molinio-Arrhenatheretea class and placed among the synonyms of the alliance Agrostion vinealis Sipailova et al. 1985;

- Artemisio dniproicae-Salicion acutifoliae Shevchyk et V. Solomakha 1996 (Shevchyk et al. 1996 p. 29) - also described from the Kaniv Nature Reserve, based on the holotypus of the association Artemisio dniproicaeSalicetum acutifoliae (Shevchyk \& Solomakha 1996); the association was originally placed by the authors in the class Festucetea vaginatae Soó ex Vicherek 1972; the alliance is accepted in the EuroVegChecklist but transferred to the Salicetea purpureae class;

- Rubo caesii-Amorphion fruticosae Shevchyk et V. Solomakha 1996 (Shevchyk \& Solomakha 1996 p. 24) also from Central Ukraine, with the holotypus of the association Euphorbio virgultosae-Amorphetum fruticosae; the association was included in the Salicetea purpureae class, the alliance is accepted in the EuroVegChecklist;

- Calamagrostio epigei-Populion nigrae (Shevchyk et V. Solomakha 1996) Shevchyk et V. Solomakha in I. Solomakha et. al. 2015 (Solomakha et al. 2015 p. 273) - from southern part of Ukraine; the name was introduced as a nomen novum instead of the name Rubo caesi-Amorphion fruticosae; the authors of nomen novum referred to art. $3 \mathrm{k}$ of the ICPN. From this point of view, we cannot accept the legitimacy of the new name Calamagrostio epigei-Populion nigrae, because art. $3 \mathrm{k}$ of the ICPN cannot be applied - the alliance Rubo caesiiAmorphion fruticosae unites the shrub communities with Amorpha fruticosa dominated in the main layer, so the name Calamagrostio epigei-Populion nigrae seems to be a nomen superfluum (ICPN, art. 18b), at least in such an interpretation;

- Poo angustifoliae-Ulmion laevis Golub in Golub et E.G. Kuzmina 1997 (Golub \& Kuzmina 1997 p. 207) from the steppe part of Russia, the valley of the Volga River. This alliance is distributed much more to the south than our communities, although it represents a related synmorphologically and ecologically type of open-canopy gallery riparian forests, with a gradual series towards open grassy communities. To the south, in the steppe part of Ukraine, especially in the floodplain of the Dnieper, this alliance is likely to be found. Later, the alliance was transferred by the authors to the order Alno-Fraxinetalia excelsioris Passarge 1968 (Golub \& Bondareva 2018); the alliance is also accepted in the EuroVegChecklist;

- Asparago officinalis-Salicion albae Golub 2001 (Golub 2001 p. 17) - also from the steppe part of Russia, the Volga-Akhtuba district; the holotypus is the association Achilleo septentrionalis-Populetum nigrae Golub et E.V. Kuzmina in Golub 2001; in the EuroVegChecklist the alliance is considered as synonym for Salicion albae Soó 1951. Nevertheless, in such distant continental regions the floristic and geographical grounds for delimiting a new alliance, a vicariate of the central European Salicion albae, are sufficient and it was shown in detail in the later publication by Golub \& Bondareva 2017;

- Agrostio vinealis-Salicion acutifoliae Bulokhov in Bulokhov et Semenishchenkov 2015 (Bulokhov \& Semenishchenkov 2015 p. 31) - from northwest part of Russia, Bryansk region, forest zone; in the EuroVegChecklist the alliance is considered synonymous with Artemisio dniproicae-Salicion acutifoliae, described from Ukraine. But perhaps this decision did not take into account that the authors validated this alliance in a separate publication later (Bulokhov \& Semenishchenkov 2015), and therefore the alliance deserves an independent status, and not as a synonym.

In Ukrainian publications, different communities were mixed within one too broadly interpreted association Salici albae-Populetum nigrae. Only in the case of units of high ranks (orders or classes), this would be acceptable, but such broad misinterpretation is not reasonable for associations. Salici-Populetum nigrae is based on a completely different pool of Central European flora and should not be included in the syntaxonomic scheme for more continental regions.

In Table 6, we summarized the results of the comparison of associations of riparian forests. This is part of a differentiating table in which we have omitted rare species and low constancy values below 20\%. For comparison, the holotype of the aforementioned Central European association Salici-Populetum nigrae is placed in column 9. 
Table 6: Comparative study of the syntaxa of riparian forests.

Tabela 6: Primerjalna analiza obrežnih gozdov.

\begin{tabular}{|c|c|c|c|c|c|c|c|c|c|}
\hline ID syntaxa & 1 & 2 & 3 & 4 & 5 & 6 & 7 & 8 & 9 \\
\hline Number of relevés & 39 & 5 & 4 & 4 & 6 & 6 & 33 & 20 & 7 \\
\hline Populus nigra & III & V & . & V & V & V & . & $\mathrm{V}$ & III \\
\hline Aristolochia clematitis & $\mathrm{V}$ & . & V & V & . & . & $\mathrm{V}$ & . & . \\
\hline Asparagus officinalis & IV & II & $\mathrm{V}$ & IV & . & . & III & V & . \\
\hline Carex praecox & . & . & IV & III & . & . & IV & III & . \\
\hline Elymus repens (Elytrigia repens) & . & II & III & . & III & . & $\mathrm{V}$ & III & . \\
\hline Galium verum & III & . & $\mathrm{V}$ & . & . & . & IV & . & \\
\hline Tanacetum vulgare & III & . & $\mathrm{V}$ & IV & . & . & . & . & . \\
\hline Euphorbia virgata & . & . & IV & $\mathrm{V}$ & . & . & III & . & . \\
\hline Bromus inermis (Bromopsis inermis) & & . & $\mathrm{V}$ & $\mathrm{V}$ & . & & . & IV & . \\
\hline Rubus caesius & III & . & . & . & . & $\mathrm{V}$ & IV & . & . \\
\hline Salix alba & & V & . & . & II & $\mathrm{V}$ & . & . & IV \\
\hline Carex hirta & III & . & . & . & II & . & . & . & . \\
\hline Lysimachia nummularia & III & . & . & . & II & . & . & . & III \\
\hline Poa pratensis & IV & . & - & . & II & . & . & . & . \\
\hline Pinus sylvestris & III & . & V & . & . & . & . & . & . \\
\hline Equisetum pratense & III & . & . & $\mathrm{V}$ & . & & . & . & \\
\hline Acer negundo & III & . & . & . & III & III & . & . & . \\
\hline Cornus sanguinea (Swida sanguinea) & & . & . & . & II & $\mathrm{V}$ & . & . & . \\
\hline Galium aparine & IV & . & . & & III & $\mathrm{V}$ & . & . & III \\
\hline Urtica dioica & . & . & . & . & III & $\mathrm{V}$ & . & . & $\mathrm{V}$ \\
\hline Arctium lappa & . & . & . & & . & III & IV & . & . \\
\hline Calamagrostis epigejos & . & . & III & IV & . & . & V & . & . \\
\hline Carex melanostachya & . & . & . & . & . & . & $\mathrm{V}$ & IV & . \\
\hline Cirsium arvense & . & & . & . & . & . & IV & III & . \\
\hline Fallopia convolvulus & . & . & III & . & . & . & III & . & . \\
\hline Glechoma hederacea & . & . & . & . & III & & III & . & II \\
\hline Lactuca serriola & . & . & . & . & II & . & IV & . & . \\
\hline Poa angustifolia & . & . & $\mathrm{V}$ & IV & . & . & $\mathrm{V}$ & . & . \\
\hline Ulmus laevis & IV & . & . & . & . & . & IV & . & . \\
\hline Convolvulus arvensis & . & . & . & . & . & . & IV & IV & . \\
\hline Galium rubioides & III & . & . & . & . & . & . & IV & . \\
\hline Alopecurus pratensis & III & . & . & . & . & . & . & . & . \\
\hline Betula pendula & III & . & . & . & . & . & . & . & . \\
\hline Cornus sanguinea & III & . & & . & . & . & . & . & . \\
\hline Erigeron annuиs & III & . & . & . & . & . & . & . & . \\
\hline Geum urbanum & III & . & & . & . & . & . & . & . \\
\hline Ligustrum vulgare & III & . & . & . & . & . & . & . & . \\
\hline Rumex thyrsiflorus & IV & . & . & . & . & . & . & . & . \\
\hline Sedum telephium & IV & . & . & . & . & . & . & . & . \\
\hline Amorpha fruticosa & . & V & . & . & . & . & . & . & . \\
\hline Bromus sterilis (Anisantha sterilis) & . & II & . & . & . & . & . & . & . \\
\hline Elaeagnus angustifolia & . & III & . & . & . & . & . & . & . \\
\hline Lithospermum officinale & . & II & . & . & . & . & $\cdot$ & . & . \\
\hline Secale sylvestre & . & II & . & . & . & . & . & . & . \\
\hline Silene vulgaris (Oberna behen) & . & II & . & . & . & . & . & . & . \\
\hline Erysimum marschallianum & . & . & & III & . & . & . & . & . \\
\hline Frangula alnus & . & . & . & III & . & . & . & . & . \\
\hline Galium boreale & . & . & . & IV & . & & . & . & \\
\hline
\end{tabular}




\begin{tabular}{|c|c|c|c|c|c|c|c|c|c|}
\hline ID syntaxa & 1 & 2 & 3 & 4 & 5 & 6 & 7 & 8 & 9 \\
\hline Number of relevés & 39 & 5 & 4 & 4 & 6 & 6 & 33 & 20 & 7 \\
\hline Galium verticillatum & . & . & . & V & . & . & . & . & \\
\hline Salix acutifolia & . & . & . & III & . & . & . & . & \\
\hline Ulmus glabra & . & . & . & III & . & . & . & . & \\
\hline Anthriscus sylvestris & . & . & . & . & II & . & . & . & \\
\hline Arrhenatherum elatius & . & . & . & . & . & IV & . & . & \\
\hline Equisetum arvense & . & . & . & . & . & IV & . & . & \\
\hline Humulus lupulus & . & . & . & . & . & III & . & . & III \\
\hline Impatiens glandulifera & . & . & . & . & . & III & . & . & \\
\hline Phalaris arundinacea (Phalaroides arundinacea) & . & . & . & . & . & $\mathrm{V}$ & . & . & \\
\hline Poa palustris & . & . & . & . & . & $\mathrm{V}$ & . & . & II \\
\hline Populus alba & . & . & . & . & . & IV & . & . & \\
\hline Salix fragilis & . & . & . & . & . & III & . & . & III \\
\hline Solidago canadensis & . & . & . & . & . & $\mathrm{V}$ & . & . & . \\
\hline Symphyotrichum novi-belgii (Aster novi-belgii) & . & . & . & . & . & III & . & . & . \\
\hline Agrimonia eupatoria & . & . & . & . & . & . & IV & . & . \\
\hline Artemisia austriaca & . & . & . & . & . & . & III & . & . \\
\hline Artemisia pontica & . & . & . & . & . & . & IV & . & \\
\hline Cannabis sativa & . & . & . & . & . & . & IV & . & . \\
\hline Carex riparia & . & . & & & . & . & III & . & . \\
\hline Chaiturus marrubiastrum & . & . & . & . & . & . & III & . & . \\
\hline Eryngium planum & . & . & . & & . & . & IV & . & . \\
\hline Euphorbia palustris & . & . & . & . & . & . & IV & . & . \\
\hline Lactuca tatarica & . & . & . & . & . & . & IV & . & . \\
\hline Lathyrus incurvus & . & . & . & . & . & . & IV & . & . \\
\hline Medicago sativa & . & . & . & . & . & . & III & . & . \\
\hline Prunus spinosa & . & . & . & . & . & . & III & . & . \\
\hline Quercus robur & . & . & . & . & . & . & V & . & . \\
\hline Sonchus arvensis & . & . & . & . & . & . & III & . & . \\
\hline Taraxacum officinale & . & . & . & . & . & . & III & & . \\
\hline Achillea salicifolia & . & . & . & . & . & . & . & III & . \\
\hline Agrostis stolonifera & . & . & . & . & . & . & . & IV & . \\
\hline Allium angulosum & . & . & . & . & . & . & . & III & \\
\hline Althaea officinalis & . & . & . & . & . & . & . & III & \\
\hline Artemisia abrotanum & . & . & . & . & . & . & . & III & \\
\hline Euphorbia esula & . & . & . & . & . & . & . & IV & \\
\hline Fraxinus pennsylvanica & . & . & . & . & . & . & . & III & \\
\hline Hierochloe repens & . & . & . & . & . & . & . & III & . \\
\hline Inula britannica & & . & . & . & . & . & . & $\mathrm{V}$ & . \\
\hline Lythrum virgatum & . & . & . & . & . & . & . & III & . \\
\hline Rubia tatarica & & . & . & . & . & & . & $\mathrm{V}$ & . \\
\hline Solanum kitagawae & . & . & . & . & . & . & . & III & . \\
\hline Stachys palustris & . & . & . & . & . & . & . & III & \\
\hline Vicia cracca & . & . & . & . & . & . & . & III & . \\
\hline Xanthium albinum & . & . & . & . & . & . & . & $\mathrm{V}$ & \\
\hline Calamagrostis lanceolata & . & . & . & . & . & . & . & . & III \\
\hline Calystegia sepium & . & . & . & . & . & . & . & . & IV \\
\hline Carex echinata & . & . & . & . & . & . & . & . & IV \\
\hline Cirsium palustre & . & . & & . & . & . & . & . & III \\
\hline Equisetum palustre & . & . & . & . & . & . & . & . & III \\
\hline Filipendula ulmaria & . & . & . & . & . & . & . & . & V \\
\hline
\end{tabular}




\begin{tabular}{|c|c|c|c|c|c|c|c|c|c|}
\hline ID syntaxa & 1 & 2 & 3 & 4 & 5 & 6 & 7 & 8 & 9 \\
\hline Number of relevés & 39 & 5 & 4 & 4 & 6 & 6 & 33 & 20 & 7 \\
\hline Galium palustre & . & . & . & . & . & . & . & . & IV \\
\hline Iris pseudacorus & . & . & . & . & . & . & . & . & $\mathrm{V}$ \\
\hline Juncus effusus & . & . & . & . & . & . & . & . & III \\
\hline Lycopus europaeus & . & . & . & . & . & . & . & . & III \\
\hline Lysimachia vulgaris & . & . & . & . & . & . & . & . & IV \\
\hline Lythrum salicaria & . & . & . & . & . & . & . & . & III \\
\hline Mentha aquatica & . & . & . & . & . & $\cdot$ & . & . & III \\
\hline Myosotis scorpioides & . & . & . & . & . & . & . & . & III \\
\hline Phragmites communis & . & . & . & . & . & . & . & . & III \\
\hline Ranunculus acris & . & . & . & . & . & . & . & . & IV \\
\hline Salix viminalis & . & . & . & . & . & . & . & . & III \\
\hline Scutellaria galericulata & . & . & . & . & . & . & . & . & III \\
\hline Solanum dulcamara & . & . & . & . & . & . & . & . & V \\
\hline Symphytum officinale & . & . & . & . & . & . & . & . & V \\
\hline Valeriana officinalis & . & . & . & . & . & . & . & . & III \\
\hline
\end{tabular}

Syntaxa: 1 - Aristolochio clematitis-Populetum nigrae (Ukraine, Kyiv region), 2 - Salici-Populetum (Ukraine, Kherson region) (Dubyna \& Dziuba 2014), 3 - Galio veri-Aristolochietum clematitis typicum, var. Pinus sylvestris (Ukraine, Cherkasy region) (Shevchyk et al. 1996), 4 - Galio veri-Aristolochietum clematitis typicum, var. Populus nigra (Ukraine, Cherkasy region) (Shevchyk et al. 1996), 5 - Galio veri-Populetum nigrae Solomakha, Smoliar et Smagliuk 2016 (Ukraine, Poltava region) (Solomakha et al. 2016), 6 - Salici-Populetum (Southwestern Slovakia) (Vojtková et al. 2014), 7 - Poo angustifoliae-Quercetum roboris Golub et Kuzmina 1997 (Russia, Volga-Akhtuba region) (Golub \& Bondareva 2018), 8 - Achilleo septentrionalis-Populetum nigrae Golub et Kuzmina in Golub 2001 (Russia, Volga-Akhtuba region) (Golub \& Bondareva 2017), 9 - Salici albae-Populetum nigrae (holotypus) Meyer-Drees 1936 (Netherlands, Achterhoek region)

Communities growing in wet conditions are generally considered to be quite homogeneous and have a wide distribution range. But as can be seen from Table 6, it's not really like that. Changes in climatic conditions significantly affect the floristic differences of syntaxa of this type. When comparing columns 8 (continental region) and 9 (suboceanic region), they have very few common species and in relation to column 1 (Kyiv region). Ukrainian communities are somewhere in the intermediate position.

Also, Table 6 confirms that association Aristolochio clematitis-Populetum nigrae cannot be seen as identical to other known associations from Ukraine. The expected distribution range of this association most likely covers floodplains in the lower courses of the left-bank tributaries of the Dnieper in the forest-steppe part of Ukraine, especially in habitats with powerful sandy sediments. These communities were often characterized as "shortterm flooded lowland forests" and reported for many regions in the Left-Bank Ukraine - in the floodplains of Vorksla, Psel, Sula, Uday, Merla rivers (Tkach 2001). To the south, communities are becoming rarer with a gradual series from mesic riparian forests to xeric sandy steppes.

\section{2, 3. Galio aparines-Aceretum negundi ass. nova hoc loco}

Dom.: Acer negundo, Robinia pseudoacacia

Const.: Parthenocissus quinquefolia, Rubus caesius, Geum urbanum, Urtica dioica, Chelidonium majus

Diff.: Galium aparine, Geranium robertianum, Chaerophyllum temulum, Impatiens parviflora, Myosotis sparsiflora

EUNIS: G5.2 - Small broadleaved deciduous anthropogenic woodlands

Holotypus: relevé 379 (Table S1); author: H. Yatsenko; date: 11.05.2016; locality: Ukraine, Kyiv city, the Venetian island; in a subspontaneous grove with a mixture of ash-leaved maple, poplar and other riparian tree species, coordinates: $50.4402^{\circ} \mathrm{N}, 30.5842^{\circ} \mathrm{E}$; total coverage of layers: trees $-80 \%$, shrubs $-20 \%$, herbs $-90 \%$. Acer negundo 3, Acer platanoides +, Alliaria petiolata 2, Carex contigua +, Carpinus betulus +, Chaerophyllum temulum + , Cornus sanguinea +, Dactylis glomerata + , Festuca gigantea +, Galium aparine 2, Geranium robertianum +, Geum urbanum 1, Glechoma hederacea +, Lysimachia nummularia +, Malus sylvestris +, Melandrium album +, Moehringia trinervia,+ Myosotissparsiflora + , Parthenocissus quinquefolia 3, Poa pratensis +, Populus nigra 2, Prunus avium + , Stellaria media 1, Taraxacum officinale + , Ulmus laevis +, Veronica chamaedrys 1, Viola odorata 2. 
Related syntaxa. Sambuco nigrae-Aceretum negundi Exner in Exner et Willner 2004, Ulmo laevis-Acericion negundi Smetana, Derpoluk et Krasova 1997 (syntax. syn. of Aegopodio podagrariae-Sambucion nigrae), Ulmo carpinifoliae-Acerion negundi Smetana, Derpoluk et Krasova 1997 (syntax. syn. of Aegopodio podagrariae-Sambucion nigrae), Galio aparine-Robinietum pseudoacaciae Smetana, Derpoluk et Krasova 1997 nom. inval. (ICPN, art. 1), Galio aparine-Ulmetum carpinifoliae Smetana, Derpoluk, Krasova 1997 nom. inval. (ICPN, art. 1), Chelidonio-Aceretum negundi L. Ishbirdina et A. Ishbirdin 1989 nom. inval. (ICPN, art. 1).

The association combines boxelder groves with a large portion of the species of Galio-Urticetea in the nutrientrich shady disturbed habitats, mainly in urban areas. Communities occur in city parks, near buildings and fences, on eroded loamy slopes. Acer negundo is widely planted in temporary climate regions and migrates primarily through riversides. It quickly reaches the epecophyte stage because of huge seed production, rapid growth, darkness-tolerance. The main limiting factor is low winter temperatures, so this aggressive invader covers only the southern part of Siberia and the Far East (south of Novosibirsk-Omsk-Khabarovsk) (Adamowski 1991).

The association Galio aparines-Aceretum negundi is reported by us using a new name. There were several reasons. The closest floristic type of communities in Ukraine is that regarded as the association Chelidonio-Aceretum negundi Ishbirdina et Ishbirdin 1989. But, as is the case with the previous association, it is too widely interpreted. This leads to the difficulties in comparative analysis since floristic differences are blurred and the distribution ranges of syntaxa become unclear. Thus, the association ChelidonioAceretum negundi was described from a region very distant from Ukraine, in Ufa (Russia, Bashkiria). In addition, this association, as well as the Chelidonio-Acerion negundi alliance based on it, was not published validly (ICPN, art. 1) (Ishbirdina et al. 1989). In addition, the another Ulmo laevis-Acericion negundi alliance was also described in Ukraine and it is not valid too (ICPN, art. 1). The authors of vegetation survey of the Czech Republic considered the Chelidonio-Acerion negundi alliance as a synonym for the Aegopodio podagrariae-Sambucion nigrae Chytrý 2013 alliance (Chytrý et al. 2013 p. 128). But this is also possible exaggeration, since it further expands the range to the west, and this time to Central Europe. Of course, synanthropic vegetation has many common features in remote regions, but it is originated from different background types of zonal natural vegetation in each region. And this gives rise to regional traits and narrows the range of these vegetation units, which, in our opinion, are misinterpreted too broadly. To demonstrate the floristic differences of known syntaxa of anthropogenous forests, a comparative analysis is necessary. (Table 7). The holotypus of the ChelidonioAceretum negundi is represented in the last column.

As can be seen from Table 7, Acer negundo is the "binding" tree species in the compared associations. This is a well-adaptable generalist, therefore floristic specificity of communities depends more not on the abundance of this species but on the soil and relief conditions in which these forests grow, and on what natural vegetation types they have derived from as a result of extensive anthropogenic pressure. For example, in our case and some other syntaxa (columns 1 and 7) there is a significant participation of nemoral species (Acer platanoides, Poa nemoralis, Ulmus glabra, Cornus sanguinea, Ulmus laevis), which act as differentiating species. This suggests that these anthropogenic forests have originated from the floodplain forests of the natural nemoral type. In the herbaceous layer, as being more vulnerable to anthropogenic pressure, indigenous forest species are missing, but in the shrub and tree layers, there are remnant natural species still. In association \#2, meadow and marsh species (Poa trivialis, Dactylis glomerata, Iris pseudacorus, and Symphytum officinale) are differential, which indicates a connection with this type of vegetation in the past.

The difference between the association Galio aparinesAceretum negundi and the next, both from the same $R o-$ binietea class, is that the first one combines groves with Acer negundo dominated in the tree layer (even if Robinia pseudoacacia present, its role is auxiliary). Although both species are neophytes, their communities differ ecologically. The Galio aparines-Aceretum negundi association combines shady forests mainly in the floodplains, whereas the groves of Robinia pseudoacacia are much more open with thermophilous species prevailing.

\section{Legend to the Table 7}

Syntaxa: 1 - Galio aparines-Aceretum negundi ass. nova hoc loco (Ukraine, Kyiv region), 2 - Rubo caesii-Aceretum negundi Batanjski et. S. Jovanović 2015 (Serbia, Zrenjanin region, Carska bara) (Batanjski et al. 2015), 3 - Chelidonio majoris-Robinietum pseudoacaciae Jurko 1963 (Czech Republic) (Chytrý et al. 2013), 4 - Chelidonio majoris-Robinietum pseudoacaciae (Czech Republic) (Vítková \& Kolbek 2010), 5 - ChelidonioAceretum negundi typicum (Russia, Kursk region) (Arepieva 2013), 6 - Chelidonio-Aceretum negundi sambucetosum nigrae (Russia, Kursk region) (Arepieva 2013), 7 - Chelidonio-Aceretum negundi (Ukraine, Cherkasy region) (Shevchyk et al. 1996), 8 - Chelidonio-Aceretum negundi (Russia, Bashkiria, Salavat city) (Golovanov \& Abramova 2013), 9 - Chelidonio-Aceretum negundi (Ukraine, Poltava region) (Smahliuk 2016), 10 - Chelidonio-Aceretum negundi (holotypus) (Russia, Bashkiria, Ufa city) (Ishbirdina et al. 1989) 
Table 7: Comparative study of the syntaxa of the Robinietea class. Rare species and I-II constancy values are not shown.

Tabela 7: Primerjalna analiza sintaksonov razreda Robinieted. Redke vrste in vrste s stalnostjo I-II niso prikazane.

\begin{tabular}{|c|c|c|c|c|c|c|c|c|c|c|}
\hline Species / Syntaxa numbers & 1 & 2 & 3 & 4 & 5 & 6 & 7 & 8 & 9 & 10 \\
\hline Number of relevés & 26 & 20 & 152 & 174 & 8 & 6 & 3 & 10 & 4 & 12 \\
\hline Acer negundo & $\mathrm{V}$ & $\mathrm{V}$ & . & . & V & $\mathrm{V}$ & $\mathrm{V}$ & $\mathrm{V}$ & $\mathrm{V}$ & $\mathrm{V}$ \\
\hline Galium aparine & $\mathrm{V}$ & . & $\mathrm{V}$ & $\mathrm{V}$ & . & . & IV & . & IV & . \\
\hline Geum urbanum & $\mathrm{V}$ & . & IV & $\mathrm{V}$ & IV & IV & . & . & III & . \\
\hline Sambucus nigra & III & . & $\mathrm{V}$ & $\mathrm{V}$ & $\mathrm{V}$ & $\mathrm{V}$ & IV & . & $\mathrm{V}$ & . \\
\hline Urtica dioica & III & III & $\mathrm{V}$ & $\mathrm{V}$ & IV & $\mathrm{V}$ & IV & IV & $\mathrm{V}$ & V \\
\hline Chelidonium majus & III & . & IV & III & IV & IV & . & IV & $\mathrm{V}$ & V \\
\hline Alliaria petiolata & $\mathrm{V}$ & . & . & . & IV & III & . & . & III & . \\
\hline Impatiens parviflora & IV & . & III & III & . & . & IV & . & . & . \\
\hline Rubus caesius & IV & IV & . & . & . & . & . & . & . & . \\
\hline Poa trivialis & . & III & . & III & . & . & . & . & . & . \\
\hline Geranium robertianum & . & . & III & III & . & . & . & . & . & . \\
\hline Robinia pseudoacacia & . & . & $\mathrm{V}$ & $\mathrm{V}$ & . & . & IV & . & IV & . \\
\hline Rubus fruticosus & . & . & III & III & . & . & . & . & . & . \\
\hline Ballota nigra & . & . & . & III & III & $\mathrm{V}$ & . & . & . & \\
\hline Acer platanoides & III & . & . & . & . & . & IV & III & IV & . \\
\hline Chaerophyllum temulum & . & . & . & III & . & . & $\mathrm{V}$ & . & . & . \\
\hline Myosotis sparsiflora & . & . & . & . & . & . & $\mathrm{V}$ & & III & . \\
\hline Arctium lappa & . & . & . & . & . & . & . & $\mathrm{V}$ & III & . \\
\hline Taraxacum officinale & . & . & . & . & IV & . & . & $\mathrm{V}$ & . & V \\
\hline Anthriscus sylvestris & . & . & III & IV & . & . & . & . & $\mathrm{V}$ & . \\
\hline Cornus sanguinea & III & . & . & . & . & . & . & . & . & . \\
\hline Parthenocissus quinquefolia & $\mathrm{V}$ & . & . & . & . & . & . & . & . & . \\
\hline Stellaria media & III & . & . & . & . & . & . & . & . & . \\
\hline Ulmus laevis & IV & . & . & . & . & . & . & . & . & . \\
\hline Viola odorata & IV & . & . & . & . & . & . & . & . & . \\
\hline Dactylis glomerata & . & III & . & . & . & . & . & . & . & . \\
\hline Iris pseudacorus & . & III & . & . & . & . & . & . & . & . \\
\hline Symphytum officinale & . & III & . & . & . & . & . & . & . & . \\
\hline Arctium tomentosum & . & . & . & . & . & $\mathrm{V}$ & . & . & . & IV \\
\hline Calystegia sepium & . & . & . & . & . & III & . & . & . & . \\
\hline Humulus lupulus & . & . & . & . & . & . & IV & . & . & . \\
\hline Poa nemoralis & . & . & . & . & . & . & IV & . & . & . \\
\hline Ulmus glabra & . & . & . & . & . & . & IV & . & . & . \\
\hline Artemisia absinthium & . & . & . & . & . & . & . & III & . & \\
\hline Artemisia vulgaris & . & . & . & . & . & . & . & $\mathrm{V}$ & . & III \\
\hline Atriplex patula & . & . & . & . & . & . & . & $\mathrm{V}$ & . & . \\
\hline Cynoglossum officinale & . & . & . & . & . & . & . & III & . & . \\
\hline Glechoma hederacea & . & . & . & . & . & . & . & III & . & . \\
\hline Lactuca serriola & . & . & . & . & . & . & . & III & . & III \\
\hline Leonurus quinquelobatus & . & . & . & . & . & . & . & $\mathrm{V}$ & . & III \\
\hline Poa pratensis & . & . & . & . & . & . & . & III & . & . \\
\hline Sorbus aucuparia & . & . & . & . & . & . & . & IV & . & III \\
\hline Adoxa moschatellina & . & . & . & . & . & . & . & . & $\mathrm{V}$ & . \\
\hline Festuca gigantea & . & . & . & . & . & . & . & . & III & . \\
\hline Ficaria verna & . & . & . & . & . & . & . & . & IV & . \\
\hline Lamium maculatum & . & . & . & . & . & . & . & . & III & . \\
\hline Myosoton aquaticum & . & . & . & . & . & . & . & . & III & . \\
\hline Pastinaca sylvestris & . & . & . & . & . & . & . & . & . & III \\
\hline Lapsana communis & . & . & . & . & . & . & . & . & . & III \\
\hline Chenopodiastrum hybridum & . & . & . & . & . & . & . & . & . & III \\
\hline Sambucus racemosa & . & . & . & . & . & . & . & . & . & III \\
\hline
\end{tabular}




\section{4, 5. Balloto nigrae-Robinietum pseudoacaciae Jurko 1963}

Dom.: Robinia pseudoacacia

Const.: Sambucus nigra, Geum urbanum, Urtica dioica, Chelidonium majus

Diff.: Impatiens parviflora, Ballota nigra

EUNIS: G1.C - Highly artificial broadleaved deciduous forestry plantations, I2.23 - Small parks and city squares

Related syntaxa. Impatienti parviflorae-Robinietum Sofron 1967, Urtico dioicae-Robinietum Ščepka 1982

Communities develop on nutrient-rich mesic to dry soils and occur in various disturbed territories - in city parks, roadside shelterbelts, wastelands, on ruderal slopes etc, and especially in warm sun-exposed sites. Tree layer is partly or fully artificial, and dominated by the neophyte of Robinia pseudiacacia. Most species are aliens of North American origin. Sometimes, the whole Robinietea class is interpreted as a synonym of the classes Rhamno-Prunetea (Šilc \& Čarni 2012, Sádlo et al. 2013), Galio-Urticetea (Vítková \& Kolbek 2010). It is more traditional for Ukrainian syntaxonomy to accept the Robinietea class in its original narrow sense (Hadač \& Sofron 1980). In the class, the Chelidonio majorisRobinion pseudoacaciae alliance is a central type widely distributed in Europe (Vítková \& Kolbek 2010, Sádlo et al. 2013). This is also reported from many locations in Ukraine (Kramarets et al. 1992, Solomakha 2008, Smahliuk 2016) and Russia (Arepieva 2011). There is less information from Siberian regions. For example, in Bashkiria the Chelidonio-Acerion negundi alliance is reported from the Robinietea class (Golovanov \& Abramova 2013). This can be explained by the limitations for the thermophilous retinue of Robinia pseudiacacia groves due to stronger climatic conditions and lower winter temperatures.

\section{Carici remotae-Fraxinetum excelsioris Koch ex} Faber 1936

Dom.: Alnus glutinosa, Fraxinus excelsior

Const.: Prunus padus, Urtica dioica

Diff.: Carex remota, Scirpus sylvaticus, Cardamine amara, Chrysosplenium alternifolium, Athyrium filix-femina, Carex sylvatica, Festuca gigantea

EUNIS: G1.21 - Riverine ash-alder woodland

Related syntaxa. Ficario-Ulmetum minoris Knapp 1942, Fraxino excelsioris-Alnetum glutinosae (Matuszkiewicz 1952) Julve 1993 ex de Foucault 1994, Carici remotaeAlnetum glutinosae Lemée 1937, Rubo caesii-Alnetum Stecyuk 1995, Convallario-Padietum Bajrak 1996
The association comprises transitional communities between the classes Carpino-Fagetea and Alnetea glutinosae. This vegetation type is widely distributed in temperate Europe and also occurs in Ukraine (Douda et al. 2016). Tree layer is co-dominated by Alnus glutinosa, Fraxinus excelsior, Quercus robur, and Ulmus glabra. Herbaceous layer is composed mainly of nutrient-demanding shade-tolerant dicots and neutrophylic low-grown sedges. The association develops under wetter conditions than Ficario-Ulmetum minoris, but not so much as communities of the Alnetea glutinosae class. Communities do not occupy large areas and occur sporadically in shady nutrient-rich sites: alongside small streams, near springs, in the bottom of forested ravines. They can be found in various depressions with poor drainage, but at a higher hypsometric level than bogs usually develop. Microclimate conditions are damp and shady.

\section{7-11. Galeobdoloni luteae-Carpinetum betuli Shevchyk, Bakalyna et V. Solomakha 1996}

Dom.: Quercus robur, Carpinus betulus, Tilia cordata, Acer platanoides, Ulmus glabra

Const.: Acer campestre, Corylus avellana, Sambucus nigra, Euonymus verrucosus, Aegopodium podagraria, Galeobdolon luteum, Asarum europaeum, Stellaria holostea, Urtica dioica

Diff.: Dryopteris filix-mas, Mercurialis perennis, Carex pilosa, Galium odoratum, Polygonatum multiflorum, Pulmonaria obscura

EUNIS: G1.A162 - Sub-continental mixed lime-oakhornbeam forests

Related syntaxa. Tilio cordatae-Carpinetum Traczyk 1962, Polygonato odorati-Carpinetum betuli Vorobyov et al. 2008, Stellario holosteae-Aceretum platanoidis Bajrak 1996, Lamio maculati-Quercetum roboris Bulokhov 1989

Within the association, we identified several variants:

- Galeobdoloni-Carpinetum var. Acer campestre - upper parts of slopes;

- Galeobdoloni-Carpinetum var. Prunus avium - no specific preferences in relief conditions;

- Galeobdoloni-Carpinetum var. Mercurialis perennis lower parts of shady slopes;

- Galeobdoloni-Carpinetum var. Carex pilosa - tends to occur on steep slopes with good drainage.

The association unites mesic oak-hornbeam forests on nutrient-rich soils. In the Dnieper basin, the Carpinion betuli alliance is on the easternmost border of its geographic range. Due to climate continentality, many western suboceanic species disappear, and communities become poorer and less specific. In this regard, Ukrain- 
ian and Russian phytosociologists introduced two other alliances as vicariants of the western Carpinion alliance. In Ukraine, Onyshchenko (2009) proposed a new name Scillo sibericae-Quercion roboris. In Russia, related communities were placed in the Querco roboris-Tilion alliance (Bulokhov \& Solomeshch 2003). In the study region, within the range of Carpinus betulus, we suppose oakhornbeam forests might be still included in the Carpinion alliance and the closest type is the association Galeobdoloni-Carpinetum, described from the Kaniv Nature Reserve (Shevchyk et al. 1996).

Communities develop on rugged relief and elevated watersheds. In the depths of forest massifs and on slopes of ravines, they are still preserved and quite natural in species composition (Actaea spicata, Epipactis helleborine, Lilium martagon, Neottia nidus-avis, Paris quadrifolia), even in urban conditions. They have a two-layered structure formed with indigenous tree species. There is a notable difference in proportions of species of the first and the second classes (Table 4, "diff" column). This is also characteristic of natural communities (most anthropogenic communities demonstrate just the opposite trend in this table). Like previous association, these forests need protection as a type in which endangered species grow in urban area.

\section{Acer platanoides+Lapsana community}

Dom.: Acer platanoides, Quercus robur, Tilia cordata

Const.: Sambucus nigra, Urtica dioica, Impatiens parviflora, Geum urbanum, Viola odorata

Diff.: Lapsana communis, Glechoma hederacea, Scrophularia nodosa, Torilis japonica, Rumex sylvestris, Anthriscus sylvestris

EUNIS: G5.2 - Small broadleaved deciduous anthropogenic woodlands

Related syntaxa. Chaerophillo temuli-Aceretum platanoidis Kramarets et al. 1992 nom. invalid. (ICPN, art. 5), Galeobdoloni luteae-Carpinetum betuli subass. impatientosum parviflorae Goncharenko, Ignatyuk et Shelyag-Sosonko 2013

This is a type of forests of natural origin but transformed under recreational use. On the one hand, the tree layer is still dominated by indigenous species (Quercus robur, Carpinus betulus etc.). On the other hand, as a result of the devastating urban recreation, herb layer consists of most synanthropic species, especially from the class $\mathrm{Gal}$ io-Urticetea. In the species composition, 32\% species are from Galio-Urticetea and 25\% species - from CarpinoFagetea (Table 4). Because floristic composition of these stands is not very unique, we see such a vegetation cluster as "community", a provisional unit of vegetation, which can then be assigned a rank in the system when more evidence is available (Westhoff \& Van der Maarel 1978).

\section{3-16. Dryopterido carthusianae-Pinetum sylvestris} ass. nov. hoc loco

Dom.: Quercus robur, Pinus sylvestris

Const.: Rubus caesius, Frangula alnus, Prunus serotina, Sorbus aucuparia, Convallaria majalis

Diff.: Dryopteris carthusiana, Pteridium aquilinum, Brachypodium sylvaticum, Luzula pilosa, Poa nemoralis, Milium effusum, Maianthemum bifolium, Elymus caninus

EUNIS: G4.7 - [Pinus sylvestris] woodland south of the taiga (G3.4) intimately mixed with acidophilous [Quercus] woodland (G1.8)

Holotypus: relevé 484 (Table S1); author: H. Yatsenko; date: 06.06.2016; locality: Ukraine, Kiev suburbs, Puscha-Voditsa locality; coordinates: $50.5424^{\circ} \mathrm{N}, 30.3262^{\circ}$ $\mathrm{E}$; total coverage of layers: trees $-60 \%$, shrubs $-50 \%$, herbs $-80 \%$. Carex ericetorum + , Convallaria majalis 1, Corylus avellana + , Dryopteris carthusiana 2, Festuca ovina 1, Frangula alnus +, Galeopsis bifida 1, Brachypodium sylvaticum +, Hypericum perforatum +, Impatiens parviflora 2, Luzula pilosa 2, Moehringia trinervia 2, Pilosella officinarum +, Pinus sylvestris 3, Poa nemoralis +, Prunus padus 2, Prunus serotina 3, Pteridium aquilinum 2, Quercus robur 1, Rubus idaeus +, Urtica dioica +, Veronica chamaedrys + , Veronica officinalis 2, Viola tricolor subsp. matutina 1 .

Related syntaxa. Calamagrostio arundinaceae-Quercetum petraeae (Hartmann 1934) Scamoni et Pass. 1959 em. Brzeg, Kasprowicz et Krotoska 1989, Betulo pendulaeQuercetum roboris R. Tx. 1930, Trientalo europaeaeQuercetum roboris Vorobyov 2014, Querco roboris-Pinetum Matuszkiewicz 1981, Pino-Quercetum Kozłowska 1925, Vaccinio myrtilli-Quercetum roboris Bulokhov et Solomeshch 2003, Pulmonario obscurae-Quercetum roboris Bulokhov et Solomeshch 2003, Violo-Quercetum sensu Goncharenko 2001 non Oberdorfer 1957, Pteridio-Pinetum sylvestris Andrienko 1986 nom. invalid. (ICPN, art. 2b, 5) (Andrienko 1986), PteridioPinetum sensu Kuzemko 2001 non Andrienko 1986 (Kuzemko 2001), Pteridio-Pinetum sensu Bajrak 1997 non Andrienko 1986 (Bajrak 1997).

The association includes pine and oak-pine forests on mesic, nutrient-poor and slightly acidic soils on sandy river terraces. It cannot be classified into the VaccinioPiceetea class with only few boreal species present, as well as nemoral species are also rare. This vegetation type is distributed in north-temperate European regions - especially Poland, Calamagrostio-Quercetum (Kasprowicz 2010), Betulo-Quercetum (Matuszkiewicz 2007), Ukraine 
- Trientalo-Quercetum (Vorobyov 2014). The closest alliance might be the Pino-Quercion (currently recognized as a synonym of the Dicrano-Pinion alliance (Mucina et al. 2016)) and the closest association is Querco roboris-Pinetum that is often reported from Ukraine (Onyshchenko 2006, Solomakha 2008, Panchenko 2013). But syntaxonomic entity of Querco-Pinetum association is controversial, and some Polish authors suggest that it is close or even based on the type of the former association PinoQuercetum Kozłowska 1925 (Eawrynowicz et al. 2004, Kasprowicz 2010).

Table 8 syntheses the floristic differences of syntaxa of acidophilous pine-oak forests according to published materials. The holotypus of the Pino-Quercetum association is presented in the last column.

Table 8: Comparative study of the syntaxa of pine-oak acidophilous forests. Rare species and I-II constancy values are not shown. Tabela 8: Primerjalna analiza sintaksonov borovo-hrastovih kisloljubnih gozdov. Redke vrste in vrste s stalnostjo I-II niso prikazane.

\begin{tabular}{|c|c|c|c|c|c|c|c|c|c|c|c|c|c|c|c|c|c|c|c|}
\hline ID syntaxa & 1 & 2 & 3 & 4 & 5 & 6 & 7 & 8 & 9 & 10 & 11 & 12 & 13 & 14 & 15 & 16 & 17 & 18 & 19 \\
\hline Number of relevés & 115 & 26 & 20 & $?$ & 14 & 11 & 20 & 36 & 82 & 47 & 23 & 9 & 9 & 8 & 6 & 6 & 26 & 5 & 3 \\
\hline Pinus sylvestris & V & . & . & V & IV & IV & IV & $\mathrm{V}$ & $\mathrm{V}$ & V & V & $\mathrm{V}$ & IV & V & V & $\mathrm{V}$ & $\mathrm{V}$ & . & $\mathrm{V}$ \\
\hline Quercus robur & $\mathrm{V}$ & $\mathrm{V}$ & $\mathrm{V}$ & V & $\mathrm{V}$ & $\mathrm{V}$ & $\mathrm{V}$ & $\mathrm{V}$ & III & III & IV & IV & . & . & V & IV & $\mathrm{V}$ & $\mathrm{V}$ & $\mathrm{V}$ \\
\hline Convallaria majalis & $\mathrm{V}$ & $\mathrm{V}$ & IV & V & IV & III & . & . & . & IV & . & . & . & IV & . & III & IV & III & IV \\
\hline Betula pendula & . & $\mathrm{V}$ & $\mathrm{V}$ & . & IV & III & IV & $\mathrm{V}$ & III & III & IV & III & III & . & . & $\mathrm{V}$ & $\mathrm{V}$ & . & II \\
\hline Fragaria vesca & . & $\mathrm{V}$ & IV & IV & . & IV & . & . & . & IV & . & IV & . & IV & III & . & III & IV & IV \\
\hline Vaccinium myrtillus & . & $\mathrm{V}$ & . & $\mathrm{V}$ & $\mathrm{V}$ & III & $\mathrm{V}$ & V & $\mathrm{V}$ & $\mathrm{V}$ & $\mathrm{V}$ & $\mathrm{V}$ & . & . & . & $\mathrm{V}$ & $\mathrm{V}$ & . & $\mathrm{V}$ \\
\hline Vaccinium vitis-idaea & . & $\mathrm{V}$ & . & IV & III & . & IV & IV & $\mathrm{V}$ & IV & . & . & . & . & . & $\mathrm{V}$ & IV & . & . \\
\hline Luzula pilosa & . & III & . & III & $\mathrm{V}$ & V & IV & $\mathrm{V}$ & III & IV & IV & III & . & . & . & $\mathrm{V}$ & $\mathrm{V}$ & . & . \\
\hline Frangula alnus & . & IV & . & IV & $\mathrm{V}$ & V & $\mathrm{V}$ & $\mathrm{V}$ & III & III & IV & IV & IV & . & . & V & $\mathrm{V}$ & . & . \\
\hline Sorbus aucuparia & . & IV & III & . & $\mathrm{V}$ & IV & $\mathrm{V}$ & $\mathrm{V}$ & IV & IV & IV & $\mathrm{V}$ & . & $\mathrm{V}$ & . & V & $\mathrm{V}$ & . & . \\
\hline Trientalis europaea & . & III & IV & IV & IV & IV & $\mathrm{V}$ & IV & . & . & III & III & . & . & . & $\mathrm{V}$ & $\mathrm{V}$ & . & . \\
\hline Pteridium aquilinum & IV & IV & . & IV & III & III & IV & IV & IV & III & III & . & . & . & $\mathrm{V}$ & IV & III & $\mathrm{V}$ & IV \\
\hline Melica nutans & . & IV & IV & IV & III & III & . & . & . & . & . & . & . & IV & . & . & III & III & II \\
\hline Corylus avellana & III & IV & $\mathrm{V}$ & IV & IV & . & . & . & . & . & . & . & . & . & . & . & III & . & $\mathrm{V}$ \\
\hline Euonymus verrucosus & III & . & IV & III & . & . & . & . & . & . & . & . & . & . & . & . & III & . & IV \\
\hline Maianthemum bifolium & . & . & $\mathrm{V}$ & . & IV & V & $\mathrm{V}$ & III & . & . & . & . & . & . & . & IV & $\mathrm{V}$ & . & $\mathrm{V}$ \\
\hline Calamagrostis arundinacea & . & . & IV & $\mathrm{V}$ & III & . & . & . & . & IV & . & . & . & . & . & III & . & . & . \\
\hline Rubus saxatilis & . & IV & III & $\mathrm{V}$ & III & . & . & . & . & III & . & . & III & III & . & . & IV & . & . \\
\hline Dicranum polysetum & . & . & . & III & . & . & . & III & III & III & . & . & . & . & . & . & . & . & . \\
\hline Melampyrum pratense agg. & . & . & . & III & . & . & III & . & III & III & . & . & . & . & . & IV & III & . & $\mathrm{V}$ \\
\hline Carpinus betulus & . & . & . & . & $\mathrm{V}$ & . & . & . & . & . & III & III & . & . & . & . & . & . & $\mathrm{V}$ \\
\hline Rubus idaeus & . & . & . & . & . & V & . & . & . & III & III & $\mathrm{V}$ & . & IV & . & IV & . & . & . \\
\hline Veronica officinalis & . & . & . & . & . & III & . & . & . & III & . & III & III & III & . & . & III & . & $\mathrm{V}$ \\
\hline Dryopteris carthusiana & IV & . & . & . & IV & IV & $\mathrm{V}$ & IV & . & . & IV & $\mathrm{V}$ & $\mathrm{V}$ & IV & . & V & $\mathrm{V}$ & . & . \\
\hline Molinia caerulea & . & . & . & . & III & . & $\mathrm{V}$ & $\mathrm{V}$ & . & . & . & . & III & . & . & . & IV & . & . \\
\hline Pleurozium schreberi & . & III & . & . & . & . & . & . & $\mathrm{V}$ & $\mathrm{V}$ & IV & $\mathrm{V}$ & . & . & . & . & . & . & . \\
\hline Brachypodium sylvaticum & $\mathrm{V}$ & . & . & . & . & . & . & . & . & . & . & . & . & . & . & . & . & . & . \\
\hline Euonymus europaeus & III & . & . & . & . & . & . & . & . & . & . & . & . & . & . & . & . & . & . \\
\hline Impatiens parviflora & $\mathrm{V}$ & . & . & . & . & . & . & . & . & . & . & . & . & . & . & . & . & . & . \\
\hline Prunus serotina & IV & . & . & . & . & . & . & . & . & . & . & . & . & . & . & . & . & . & . \\
\hline Rubus caesius & III & . & . & . & . & . & . & . & . & . & . & . & . & . & . & . & . & . & . \\
\hline Sambucus nigra & III & . & . & . & . & . & . & . & . & . & . & . & . & . & . & . & . & . & . \\
\hline Ulmus laevis & III & . & . & . & . & . & . & . & . & . & . & . & . & . & . & . & . & . & . \\
\hline Urtica dioica & IV & . & . & . & . & . & . & . & . & . & . & . & . & . & III & . & . & III & . \\
\hline Galium mollugo & . & III & . & . & . & . & . & . & . & . & . & . & . & . & . & . & . & . & . \\
\hline
\end{tabular}




\begin{tabular}{|c|c|c|c|c|c|c|c|c|c|c|c|c|c|c|c|c|c|c|}
\hline ID syntaxa & 1 & 2 & 3 & 4 & 5 & 6 & 7 & 8 & 9 & 1011 & 112 & 13 & 14 & 15 & 16 & 17 & 181 & 19 \\
\hline Orthilia secunda & . & III & & . & . & . & . & . & 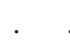 & . & . & . & . & . & . & III & & . \\
\hline Pyrola rotundifolia & . & III & & . & . & . & . & . & & . & . & . & . & . & . & . & & II \\
\hline Serratula tinctoria & . & III & III & . & . & . & . & . & & . & . & . & . & . & . & . & & . \\
\hline Viola nemoralis & . & III & & . & . & . & . & . & . & . & . & . & . & . & . & . & . & . \\
\hline Aegopodium podagraria & & . & III & . & . & . & . & . & . & . & . & . & . & . & . & . & . & . \\
\hline Epipactis helleborine & . & . & III & . & . & . & . & . & & . & . & . & . & 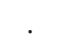 & . & . & & . \\
\hline Geranium sylvaticum & . & . & III & . & . & . & . & . & . & . & . & . & . & . & . & . & & . \\
\hline Geum urbanum & III & . & IV & . & . & . & . & . & . & . & . & . & . & . & . & . & III & . \\
\hline Lathyrus vernus & . & . & V & . & . & . & . & . & & . & . & . & . & . & . & . & . & II \\
\hline Milium effusum & . & . & III & . & . & . & . & . & & . & . & . & . & . & . & . & . & . \\
\hline Populus tremula & . & . & $\mathrm{V}$ & . & III & . & III & III & . & . & . & . & . & . & . & . & . & II \\
\hline Pulmonaria obscura & . & . & $\mathrm{V}$ & . & . & . & . & . & . & . & . & . & . & . & . & . & . & $\mathrm{V}$ \\
\hline Viola mirabilis & & . & III & & . & . & . & . & . & . & . & . & . & . & . & & . & . \\
\hline Carex digitata & . & . & . & IV & . & . & . & . & . & . & . & . & . & . & . & III & . & . \\
\hline Solidago virgaurea & . & . & . & III & . & . & . & . & & . & . & . & . & . & . & . & & \\
\hline Ajuga reptans & . & . & . & . & III & . & . & . & & . & . & . & . & . & . & . & . & \\
\hline Lysimachia vulgaris & . & . & . & . & III & III & . & . & & . & . & III & . & . & . & . & . & . \\
\hline Rubus nessensis & . & . & . & . & III & . & III & . & . & . & . & . & . & . & . & . & . & . \\
\hline Amelanchier ovalis & . & . & . & . & . & III & . & . & . & . & . & . & . & . & . & . & . & . \\
\hline Anemone nemorosa & . & . & . & . & III & IV & . & . & & . & . & . & . & & . & . & & . \\
\hline Festuca rubra & . & . & . & . & . & III & . & . & & . & . & . & . & . & . & . & & \\
\hline Galeopsis tetrahit & . & . & . & . & . & III & . & . & & . & . & . & . & . & . & & . & \\
\hline Polygonatum multiflorum & . & . & . & . & . & III & . & . & . & . & . & . & . & . & . & . & . & . \\
\hline Alnus glutinosa & . & . & . & . & . & . & III & . & . & . & . & . & . & . & . & . & . & . \\
\hline Lysimachia nummularia & & . & . & & . & . & IV & . & . & & . & . & & . & . & & IV & . \\
\hline Polytrichum commune & . & . & . & . & . & . & III & . & & . & . & . & . & . & . & . & . & . \\
\hline Rhododendron luteum & . & . & . & . & . & . & III & . & & . & . & . & . & . & . & . & . & . \\
\hline Festuca ovina agg. & . & . & . & . & . & . & . & IV I & IV I & IV & . & . & . & . & III & . & . & $\mathrm{V}$ \\
\hline Picea abies & . & . & . & . & . & . & . & III I & III & . III & . & . & . & . & . & . & . & . \\
\hline Polytrichum formosum & . & . & . & . & . & . & . & IV I & III & III & I III & . & . & . & . & . & . & . \\
\hline Oxalis acetosella & . & . & . & . & . & . & . & III & . & . & IV & . & . & . & . & . & . & II \\
\hline Carex pilulifera & . & . & . & . & . & . & . & . 1 & III & . & . & . & . & . & . & . & & . \\
\hline Dicranum scoparium & . & . & . & . & . & . & . & . & III & . & . & . & . & . & . & . & . & . \\
\hline Pohlia nutans & & . & & & . & . & . & . & III & . . & . & . & . & . & . & & . & . \\
\hline Quercus petraea & . & . & & . & . & . & . & . & III Il & III III & I III & . & . & & . & . & . & . \\
\hline Agrostis capillaris & . & . & . & . & . & III & . & . & & . . & IV & . & III & & . & . & . & $\mathrm{V}$ \\
\hline Campanula rotundifolia & . & . & . & . & . & . & . & . & & . & III & . & III & & . & . & . & . \\
\hline Carex hirta & . & . & . & . & . & . & . & . & & . & III & . & . & . & . & . & . & . \\
\hline Hypericum perforatum & . & . & . & . & . & . & . & . & & . & V & . & . & . & . & . & . & . \\
\hline Moehringia trinervia & III & . & . & . & . & . & . & . & & III & IV & . & IV & & . & . & . & . \\
\hline Mycelis muralis & . & . & & . & . & . & . & . & & . & III & . & . & . & . & . & . & . \\
\hline Pseudoscleropodium purum & & . & . & & . & . & . & III & & IV & $\mathrm{V}$ & . & & . & . & & . & . \\
\hline Rumex acetosella & . & . & . & . & . & . & . & . & & . & IV & . & IV & . & . & . & . & . \\
\hline Viola reichenbachiana & . & . & & . & . & . & . & . & & . & III & . & . & . & . & . & & $\mathrm{V}$ \\
\hline Anthoxanthum odoratum & . & . & & . & . & . & . & . & & III & III & IV & . & & . & & & \\
\hline Betula pubescens & . & . & & . & . & & III & . & & . & & IV & . & & . & . & & \\
\hline Carex leporina & . & . & & . & . & & . & . & & . & & IV & . & & . & . & & \\
\hline Carex pallescens & & & & & & & & & & & & IV & & & & & & \\
\hline
\end{tabular}




\begin{tabular}{|c|c|c|c|c|c|c|c|c|c|c|c|c|c|c|c|c|c|c|c|}
\hline ID syntaxa & 1 & 2 & 3 & 4 & 5 & 6 & 7 & 8 & 9 & 10 & 11 & 12 & 13 & 14 & 15 & 16 & 17 & 18 & 19 \\
\hline Deschampsia cespitosa & . & . & . & . & . & III & . & . & . & . & . & . & $\mathrm{V}$ & . & . & . & . & . & . \\
\hline Juncus effusus & . & . & . & . & . & . & . & . & . & . & . & . & $\mathrm{V}$ & . & . & . & . & . & . \\
\hline Potentilla erecta & . & III & . & . & . & . & . & . & . & . & . & . & IV & . & . & . & . & . & II \\
\hline Calamagrostis epigejos & . & . & . & . & . & . & . & . & . & . & . & III & . & IV & . & . & . & . & . \\
\hline Chelidonium majus & . & . & . & . & . & . & . & . & . & . & . & . & . & $\mathrm{V}$ & IV & . & . & . & . \\
\hline Elymus caninus & . & . & . & . & . & . & . & . & . & . & . & . & . & III & . & . & . & . & . \\
\hline Micarea myriocarpa & . & . & . & . & . & . & . & . & . & . & . & . & . & III & . & . & . & . & . \\
\hline Poa nemoralis & . & . & . & . & . & . & . & . & . & . & . & . & . & $\mathrm{V}$ & IV & . & . & . & . \\
\hline Silene nutans & . & . & . & . & . & . & . & . & . & . & . & . & . & III & . & . & . & . & . \\
\hline Polygonatum odoratum & . & . & . & . & . & . & . & . & . & . & . & . & . & III & . & . & . & . & . \\
\hline Betonica officinalis & . & . & . & . & . & . & . & . & . & . & . & . & . & . & III & . & . & III & . \\
\hline Lactuca serriola & . & . & . & . & . & . & . & . & . & . & . & . & . & . & IV & . & . & . & . \\
\hline Scrophularia nodosa & . & . & . & . & . & . & . & . & . & . & . & . & . & . & III & . & . & . & . \\
\hline Sedum ruprechtii & . & . & . & . & . & . & . & . & . & . & . & . & . & . & III & . & . & . & . \\
\hline Calluna vulgaris & . & . & . & . & . & . & . & . & . & . & . & . & . & . & . & III & . & . & II \\
\hline Acer platanoides & III & . & III & . & III & . & . & . & . & . & . & . & . & . & . & . & IV & . & . \\
\hline Stellaria holostea & . & . & . & III & . & III & . & . & . & . & . & . & . & . & . & . & IV & . & IV \\
\hline Asarum europaeum & . & . & . & . & . & . & . & . & . & . & . & . & . & . & . & . & . & III & II \\
\hline Clematis recta & . & . & . & . & . & . & . & . & . & . & . & . & . & . & . & . & . & $\mathrm{V}$ & . \\
\hline Clinopodium vulgare & . & IV & . & . & . & . & . & . & . & . & . & . & . & . & . & . & . & $\mathrm{V}$ & . \\
\hline Torilis japonica & . & . & . & . & . & . & . & . & . & . & . & . & . & . & . & . & . & III & . \\
\hline Veronica chamaedrys & . & . & . & . & . & . & . & . & . & . & . & . & III & . & . & . & . & IV & . \\
\hline Viola hirta & . & . & . & . & . & . & . & . & . & . & . & . & . & . & . & . & . & III & . \\
\hline Crataegus monogyna & . & . & . & . & . & . & . & . & . & . & . & . & . & . & . & . & . & . & IV \\
\hline Daphne mezereum & . & . & . & . & . & . & . & . & . & . & . & . & . & . & . & . & . & . & IV \\
\hline Galium intermedium & . & . & . & . & . & . & . & . & . & . & . & . & . & . & . & . & . & . & $\mathrm{V}$ \\
\hline Galium vernum & . & . & . & . & . & . & . & . & . & . & . & . & . & . & . & . & . & . & $\mathrm{V}$ \\
\hline Hepatica nobilis & . & . & . & . & . & . & . & . & . & . & . & . & . & . & . & . & . & . & IV \\
\hline Hieracium murorum & . & . & . & . & . & . & . & . & . & . & . & . & . & . & . & . & . & . & IV \\
\hline Hypericum montanum & . & . & . & . & . & . & . & . & . & . & . & . & . & . & . & . & . & . & $\mathrm{V}$ \\
\hline Juniperus communis & . & . & . & . & . & . & . & . & . & . & . & . & . & . & . & . & . & . & $\mathrm{V}$ \\
\hline Lactuca muralis & . & . & . & . & . & . & . & . & . & . & . & . & . & . & . & . & . & . & IV \\
\hline Lathyrus niger & . & . & . & . & . & . & . & . & . & . & . & . & . & . & . & . & . & . & $\mathrm{V}$ \\
\hline Luzula nemorosa & . & . & . & . & . & . & . & . & . & . & . & . & . & . & . & . & . & . & V \\
\hline Lysimachia borealis & . & . & . & . & . & . & . & . & . & . & . & . & . & . & . & . & . & . & V \\
\hline Melampyrum nemorosum & . & . & . & . & . & . & . & . & . & . & . & . & . & . & . & . & . & . & IV \\
\hline Pyrola secunda & . & . & . & . & . & . & . & . & . & . & . & . & . & . & . & . & . & . & IV \\
\hline Sanicula europaea & . & . & . & . & . & . & . & . & . & . & . & . & . & . & . & . & . & . & IV \\
\hline
\end{tabular}

ID Syntaxa: 1 - Dryopterido carthusianae-Pinetum sylvestris (Ukraine, Kyiv region), 2 - Vaccinio myrtilli-Quercetum roboris typicum (Russia, Bryansk region) (Semenishchenkov 2018), 3 - Pulmonario obscurae-Quercetum roboris typicum (Russia, Bryansk region) (Semenishchenkov 2018), 4 - Querco roboris-Pinetum coryletosum (Russia, Bryansk region, the "Bryansk forest" Nature Reserve) (Morozova 1999), 5, 6, 7 - Trientalo europaeae-Quercetum roboris (5 - subass. carpinietosum betuli, 6 - subass. coryletosum avellanae, 7 - subass. molinietosum caeruleae) (Ukraine, Zhitomyr Polyssya) (Vorobyov 2014), 8-12 - Querco roboris-Pinetum (8-subass. molinietosum, 9 - subass. typicum, 10 - subass. coryletosum, 11 - derivative community of Querco roboris-Pinetum typicum, 12 - derivative community of Querco roboris-Pinetum coryletosum) (Kasprowicz 2010), 13 - Querceto roboris-Betuletum (Ukraine, Sumy region) (Goncharenko 2001), 14 - Violo-Quercetum (Ukraine, Sumy region) (Goncharenko 2001), 15 - Pteridio-Pinetum (Ukraine, Cherkasy region) (Kuzemko 2001), 16, 17 - Querco roboris-Pinetum (16 - typicum, 17 - coryletosum) (Ukraine, Sumy region) (Panchenko 2013), 18 - Pteridio aquilini-Quercetum roboris (Ukraine, Poltava region) (Bajrak 1996), 19 - Pineto-Quercetum Kozłowska 1925, holotypus (Poland, Jaksice, Zarogów, Klonów regions) (Kozłowska 1925) 
Despite many of common species, almost each association has own differentiating species, as can be seen from a long tail part of the table. In Western Russia, acidophilous mixed forests were classified in a separate alliance Vaccinio myrtilli-Quercion roboris (Bulokhov \& Solomeshch 2003). Authors emphasized that communities of the Bryansk region significantly differ from those related in Central Europe and discussed this issue in detail (Semenishchenkov 2018). We also support this point of view and consider our association to be the eastern acidophilic type of mixed pine-oak forests, therefore we classified it in this alliance.

\section{Chamaecytiso zingeri-Pinetum sylvestris Vorobyov, Balaschov et V. Solomakha 1997}

Dom.: Pinus sylvestris

Const: Festuca ovina, Calamagrostis epigejos, Genista tinctoria, Cytisus ruthenicus

Diff.: Rumex acetosella, Pilosella officinarum, Hypericum perforatum, Silene nutans, Hypochaeris radicata

EUNIS: G4.72 - Continental nemoral pine-oak forests

Related syntaxa. Peucedano-Pinetum Matuszkiewicz (1962) 1973, Veronico incanae-Pinetum Bulokhov et Solomeshch 2003, Thymo serpylli-Pinetum sylvestris $\mathrm{Bu}-$ lokhov et Solomeshch 2003, Calamagrostio arundinaceae-Pinetum sylvestris Shevchyk et V. Solomakha 1996. The association includes subcontinental xeric pine forests with a herbaceous layer dominated by droughtadapted grasses. Communities cover gentle slopes of sandy dunes on river terraces. These forests are usually maintained by recurrent wildfires. Their syntaxonomical affiliation is a matter of debate. Some authors put them in a separate Pulsatillo-Pinetea sylvestris class. But it depends on the region. We believe this class is more southern one, covering the steppe and the southernmost part of foreststeppe zones. Our communities should not be attributed to the association Festuco-Pinetum sylvestris Kobendza 1930 either because many diagnostic species (Antennaria dioica, Anthericum, ramosum, Asperula tinctoria, and Brachypodium pinnatum) (Chytrý et al. 2013 p. 386) are absent. The type from the Ukrainian Polissya should be characterized as oligotrophic and acidophilic (Pogrebnyak 1955). There are similar associations of xeric pine forests - Peucedano-Pinetum from Poland (Matuszkiewicz 2007), Chamaecytisi zingeri-Pinetum from Ukraine (Vorobyov et al. 1997), and Veronico incanae-Pinetum from Western Russia (Bulokhov \& Solomeshch 2003). Most likely, these associations are vianants, replacing each other in the direction from west to east. We classified our communities in the second type of Chamaecytisi zingeri-Pinetum also relying on geographical proximity.
The absence of Cytisus zingeri (Cytisus ruthenicus agg.) in our case does not make much difference, since other characteristic species (Genista tinctoria, Hypericum perforatum, Silene nutans etc.) are common.

\section{Polygonato odorati-Quercetum roboris} (Shevchyk et V. Solomakha 1996) Goncharenko et Yatsenko nom. nov. hoc loco

Dom.: Pinus sylvestris, Quercus robur

Const.: Cytisus ruthenicus, Poa nemoralis, Convallaria majalis, Polygonatum odoratum

Diff.: Clinopodium vulgare, Betonica officinalis, Geranium sanguineum, Euphorbia cyparissias, Teucrium chamaedrys, Digitalis grandiflora, Turritis glabra, Silene nutans, Hypericum perforatum

EUNIS: G4.C - Mixed Pinus sylvestris - thermophilous Quercus woodland

Related syntaxa: Lathyro nigri-Quercetum roboris Bulokhov et Solomesch 2003, Chamaecytiso rutheniciQuercetum roboris Semenishchenkov, Poluyanov 2014, Galio tinctori-Quercetum roboris Goncharenko 2003, Pteridio aquilini-Quercetum robori Bajrak 1996, Vincetoxico hirundinariae-Quercetum roboris Sokolova 2011, Violo hirtae-Quercetum roboris Vorobyov 2017, Potentillo albae-Quercetum petraeae Libbert 1933, Potentillo albaeQuercetum roboris Bulokhov 1991

The association includes dry-mesic oak and oak-pine forests. Communities are easily identifiable due to a rich herbaceous layer consisting of light-demanding species, which are mainly characteristic for the TrifolioGeranietea class. The percentage of species of the latter class equals $22 \%$ (Table 4 ). The tree layer is mainly composed by a late phenologic form of oak species (Quercus robur var. tardiflora) with a frequent admixture of Pinus sylvestris. This association is included in the class Quercetea pubescenti-petraeae mainly following the tradition in Ukrainian syntaxonomy (Solomakha 2008). In EuroVegChecklist, the Convallario majalis-Quercion roboris alliance is considered a synonym of Aceri tatariciQuercion Zólyomi 1957, which also belongs to the Quercetea pubescenti-petraeae class. In fact, the placement of clusters 13-18 into different classes of vegetation is a more nomenclatural solution. In the study region, all three classes of vegetation - Vaccinio-Piceetea, Quercetea pubescenti-petraeae, and Quercetea robori-petraeae are outside their main distribution optima. Therefore, their communities greatly converge towards each other. This becomes especially manifested in xeric conditions.

Unfortunately, the former name Convallario majalisQuercetum roboris (as suggested by Shevchyk et al. 1996) is not legitimate. It is a later homonym of the earlier Hungarian association Convallario majalis-Quercetum 
roboris Soó (1939) 1957 (Soó 1957). We suggest replacing this name.

New name: Polygonato odorati-Quercetum roboris (Shevchyk et V. Solomakha 1996) Goncharenko et Yatsenko nom. nov. hoc loco

Synonym: Convallario majalis-Quercetum roboris sensu Shevchyk et V. Solomakha 1996 non Soó (1939) 1957 (ICPN, art. 31) (Shevchyk et al. 1996, p. 47)

Lectotypus: Table 9, relevé 7 (Shevchyk et al. 1996 p. 48)

Note: The choice of lectotype was motivated by an error (possibly a typo) made by Shevchyk et al. (1996) who used the same relevé (rel. 10 in table 9) as a holotype of - Asaro europei-Betuletum Shevchyk et V. Solomakha 1996 (Shevchyk et al. 1996 p. 46) and Convallario majalis-Quercetum roboris (Shevchyk et al. 1996 p. 47).

\section{Conclusions}

We provided the results of floristic-sociological classification of the most common types of forest vegetation of the Kyiv urban area. The syntaxonomic scheme includes 7 classes of vegetation, but most of them are represented by only one association. We stated a rather small floristic differences of communities within the Vaccinio-Piceetea, Quercetea robori-petraeae, and Quercetea pubescenti-petraeae classes. All of them are outside of their distribution optima and communities are not typical in the region. A comparative floristic analysis was conducted to confirm significant differences between the described syntaxa and western associations and some of them were proposed new ones. Anthropogenic pressure has led to a significant reduction in the total coenotic diversity of the forest vegetation of the capital. Nevertheless, in some protected areas, on the outskirts of Kyiv and on the Dnieper islands, communities with natural features are still occasionally preserved. First of all, this concerns broad-leaved forests on a rugged elevated relief. They require protection, since it is here that most of the vulnerable species are concentrated.

\section{Acknowledgments}

Authors are grateful to L. Mucina (Australia, Murdoch University) and Ya. Golovanov (Russia, South-Ural Botanical Garden-Institute of Ufa Federal Scientific Centre RAS) for providing us with some comparative material.

I. V. Goncharenko (D), https://orcid.org/0000-0001-5239-3270

H. M. Yatsenko (D), https://orcid.org/0000-0002-0917-6171

\section{References}

Adamowski, W. 1991: Naturalization of Acer negundo in the environs of Novosibirsk (West Siberia). Phytocoenosis 3: 41-42.

Andrienko, T.L. 1986: Class Vaccinio-Piceetea. Pine forests of Ukrainian Polissya. In Classification of the vegetation of the USSR (using floristic criteria), Izdatelstvo MGU, Moscow: 112-120. [In Ukrainian]

Arepieva, L.A. 2011: Phytosociological analysis of the coenofloras of ruderal vegetation classes in the cities of Bryansk and Kursk. Russian Journal of Ecology 42(5): 429-431. [In Russian]

Arepieva, L.A. 2013: Plant communities of spontaneous garbage lands in urban territories of Kursk region. Uchenye Zapiski: Elektronnyi Nauchnyi Zhurnal Kurskogo Gosudarstvennogo Universiteta 28(4). [In Russian]

Bajrak, O.M. 1996: The syntaxonomy of broad-leaved forests of the Left-Bank Dnieper Area. Ukrainskyi Fitotsenotychnyi Zbirnyk, Ser. A. 3: 51-64. [In Ukrainian]

Bajrak, O.M. 1997: The syntaxonomy of pine forests of Left-Bank Dnieper and participation in that communities of epigeic lichens. Ukrainskyi Fitotsenotychnyi Zbirnyk, Ser. A. 6: 85-92. [In Ukrainian]

Batanjski, V., Kabaš, E., Kuzmanović, N., Vukojičić, S., Lakušić, D. \& Jovanović, S. 2015: New invasive forest communities in the riparian fragile habitats - the case study from Ramsar site Carska bara (Vojvodina, Serbia). Šumarski List 139(3-4): 155-168.

Borhidi, A. 1995: Social behaviour types, the naturalness and relative ecological indicator values of the higher plants in the Hungarian flora. Acta Botanica Hungarica 39(1-2): 97-181.

Botta-Dukát, Z. \& Borhidi, A. 1999: New objective method for calculating fidelity. Example: the illyrian beechwoods. Annali di Botanica 57: 73-90.

Brock, G., Pihur, V., Datta, S. \& Datta, S. 2008: clValid: An R Package for Cluster Validation. Journal of Statistical Software 25(4): 1-22.

Bruelheide, H. 2000: A new measure of fidelity and its application to defining species groups. Journal of Vegetation Science 11(2): 167-178.

Bulokhov, A.D. \& Semenishchenkov, Yu.A. 2015: Typification and correction of forest vegetation syntaxa of the Southern Nechernozemye of Russia and adjancent regions. Biulleten Brianskogo Otdeleniia Russkogo Botanicheskogo Obshchestva 1(5): 26-32. [In Russian]

Bulokhov, A.D. \& Solomeshch, A.I. 2003: Syntaxonomy of the forests of Russian Southern Nechernosemie. BGU, Brjansk. 359 pp. [In Russian]

Charrad, M., Ghazzali, N., Boiteau, V. \& Niknafs, A. 2014: NbClust: An $\mathrm{R}$ package for determining the relevant number of clusters in a data set. Journal of Statistical Software 61(6): 1-36.

Chytrý, M., Douda, J., Roleček, J., Sádlo, J., Boublík, K., Hédl, R., Vítková, M., Zelený, D., Navrátilová, J., Neuhäuslová, Z., Petř́ik, P., Kolbek, J., Lososová, Z., Šumberová, K. \& Hrivnák, R. 2013: Vegetace České republiky. 4. Lesní a křovinná vegetace. Academia, Praha. 551 pp.

Chytrý, M. \& Tichý, L. 2003: Diagnostic, constant and dominant species of vegetation classes and alliances of the Czech Republic: a statistical revision. Folia Facultatis Scientiarum Naturalium Universitatis Masarykianae Brunensis, Biologia 108: 1-231. 
Chytrý, M., Tichý, L., Holt, J. \& Botta-Dukát, Z. 2002:

Determination of diagnostic species with statistical fidelity measures. Journal of Vegetation Science 13(1): 79-90.

Cover, T. \& Hart, P. 1967: Nearest neighbor pattern classification. IEEE Transactions on Information Theory 13(1): 21-27.

De Cáceres, M., Font, X. \& Oliva, F. 2008: Assessing species diagnostic value in large data sets: A comparison between phicoefficient and Ochiai index. Journal of Vegetation Science 19(6): 779-788.

De Cáceres, M. \& Legendre, P. 2009: Associations between species and groups of sites: indices and statistical inference. Ecology 90(12): 3566-3574.

Didukh, Y.P. 2011: The ecological scales for the species of Ukrainian flora and their use in synphytoindication. Phytosociocenter, Kyiv. $176 \mathrm{pp}$.

Didukh, Y.P. \& Chumak, K.V. 1992: Geobotanical characteristic of the reservation "Lesniki" (Kyiv). Ukrainskyi Botanichnyi Zhurnal 49(6): 22-27. [In Ukrainian]

Douda, J., Boublík, K., Slezák, M., Biurrun, I., Nociar, J., Havrdová, A., Doudová, J., Aćić, S., Brisse, H., Brunet, J., Chytrý, M., Claessens, H., Csiky, J., Didukh, Y., Dimopoulos, P., Dullinger, S., FitzPatrick, Ú., Guisan, A., Horchler, P.J., Hrivnák, R., Jandt, U., Kącki, Z., Kevey, B., Landucci, F., Lecomte, H., Lenoir, J., Paal, J., Paternoster, D., Pauli, H., Pielech, R., Rodwell, J.S., Roelandt, B., Svenning, J.-C. Šibík, J., Šilc, U., Škvorc, Ž., Tsiripidis, I., Tzonev, R.T., Wohlgemuth, T. \& Zimmermann, N.E. 2016: Vegetation classification and biogeography of European floodplain forests and alder carrs. Applied Vegetation Science 19(1): 147-163.

Dubyna, D.V. \& Dziuba, T.P. 2014: Syntaxonomical diversity of vegetation of the Dnieper River estuary area. VI. Classes Salicetea purpureae, Alnetea glutinosae. Rastitelnost Rossii 25: 13-29. [In Russian]

Frank, D. \& Klotz, S. 1990: Biologisch-Ökologische Daten zur Flora der DDR. 1-167 pp.

Golovanov, Ya.M. \& Abramova, L.M. 2013: Vegetation of Salavat city (Bashkortostan Republic). IV. Synanthropic vegetation (classes Polygono arenastri-Poëtea annuae, Galio-Urticetea and Robinietea). Vegetation on Russia 22: 11-20. [In Russian]

Golub, V. 2001: Communities of the Asparago-Salicion albae all. nova on the territory of the lower Volga valley. Ukrainskyi Fitotsenotychnyi Zbirnyk, Ser. A 1: 17-28. [In Ukrainian]

Golub, V. \& Kuzmina, E. 1997: The communities of cl. QuercoFagetea Br.-Bl. \& Vlieger in Vlieger 1937 of the Lower Volga Valley. Feddes Repertorium 108(3-4): 205-218.

Golub, V.B. \& Bondareva, V.V. 2017: Plant communities of the class Salicetea purpureae in the Lower Volga valley. Fitoraznoobrazie Vostochnoi Evropy 11(2): 21-57. [In Russian]

Golub, V.B. \& Bondareva, V.V. 2018: Communities of the class Alno glutinosae-Populetea albae P. Fukarek et Fabijanić 1968 in the valley of the Lower Volga. Fitoraznoobrazie Vostochnoi Evropy 12(3): 144-159. [In Russian]

Goncharenko, I.V. 2001: Floristic classification of the forest vegetation of the forest-steppe part of Sumy region. Ukrainskyi Fitotsenotychnyi Zbirnyk, Ser. A 17(1): 3-17. [In Ukrainian]
Goncharenko, I.V. 2015: DRSA: a non-hierarchical clustering algorithm using $\mathrm{k}-\mathrm{NN}$ graph and its application in vegetation classification. Rastitelnost Rossii 27: 125-138. [In Russian]

Goncharenko, I.V. 2016: Quality assessment of phytocoenotic classification (theoretical-methodological aspect). Chornomorskyi Botanichnyi Zhurnal 12(1): 41-50. [In Ukrainian]

Goncharenko, I.V., Ignatyuk, O.A. \& Shelyag-Sosonko, Yu.R. 2013a: Forest vegetation of the Feofaniya Tract and its anthropogenic transformation. Ekolohiia ta Noosferolohiia 24(3-4): 51-63. [In Ukrainian]

Goncharenko, I.V., Senchylo, O.O. \& Didukh, Ya.P. 2013b: Method for quantitative evaluation of plant communities using phytosociological spectrum. Chornomorskyi Botanichnyi Zhurnal 9(4): 485-496. [In Ukrainian]

Hadač, E. \& Sofron, J. 1980: Notes on syntaxonomy of cultural forest communities. Folia Geobotanica et Phytotaxonomica (15): 245-258.

Halkidi, M., Batistskis, Y. \& Vazirgiannis. M. 2001: On clustering validation techniques. Journal of Intelligent Information Systems 17(3): 107-145.

Hennekens, S.M. \& Schaminée, J.H.J. 2001: TURBOVEG, a comprehensive data base management system for vegetation data. Journal of Vegetation Science 12(12): 589-591.

Hill, M.O. \& Gauch, H.G. 1980: Detrended correspondence analysis: An improved ordination technique. Vegetatio 42(1-3): 47-58.

Ishbirdina, L.M., Ishbirdin, A.R. \& Anischenko, I.E. 1989: About some new synanthropic communities of the city of Ufa. VINITI, 6236 - B89, Moskva. 26 pp. [In Russian]

Jarolimek, I. \& Šibík, J. 2008: Diagnostic, constant and dominant species of the higher vegetation units of Slovakia. Veda, Bratislava. $332 \mathrm{pp}$.

Kasprowicz, M. 2010: Acidophilous oak forests of the Wielkopolska region (West Poland) against the background of Central Europe. Biodiversity: Research and Conservation 20(1): 1-212.

Kozłowska, A. 1925: Zmienność kostrzewy owczej (Festuca ovina L.) w związku z sukcesją zespołów stepowych na Wyżynie Małopolskiej. Sprawozdanie Komisji Fizjograficznej P.A.U. 60: 325-377.

Kozyr, M.S. 2013: Forest vegetation of "Lysa Gora» locality in Kyiv. Ekosistemy ikh Optimizatsiia i Okhrana 8: 71-77. [In Ukrainian]

Kramarets, V.O., Kucheriaviy, V.O. \& Solomakha, V.A. 1992: Park and forest park vegetation of the cities of Western Ukraine. Ukrainskyi Botanichnyi Zhurnal 49(3): 12-20. [In Ukrainian]

Kuzemko, A.A. 2001: Forest vegetation of the Ros' river valley. I. Class Vaccinio-Piceetea. Ukrainskyi Fitotsenotychnyi Zbirnyk, Ser. A 17(1): 53-65. [In Ukrainian]

Lance, G. \& Williams, W. 1966: A generalized sorting strategy for computer classifications. Nature 212(5058): 218.

Ławrynowicz, M., Bujakiewicz, A. \& Mułenko, W. 2004: Mycocoenological studies in Poland. 1952-2002. Monographiae Botanicae 93: 1-104.

Lepšs, J. \& Šmilauer, P. 2003: Multivariate Analysis of Ecological Data using CANOCO. Cambridge University Press, UK. 269 pp. 
Lyubchenko, V.M. 1983: Broad-leaved forests with Carpinus betulus L. in Kiev suburbs. Ukrainskyi Botanichnyi Zhurnal 40(1): 30-34. [In Ukrainian]

Lyubchenko, V.M. \& Padun, I.M. 1985: Present state of vegetation of the Holosyiv Park. Ukrainskyi Botanichnyi Zhurnal 42(1): 65-70. [In Ukrainian]

Lyubchenko, V.M. \& Vyrchenko, V.M. 2007: State and trends of vegetation and flora changes in the Holosyiv Forest. In Ecology of Holosievsky Forest, Phoenix, Kyiv: 35-41. [In Ukrainian]

Matuszkiewicz, W. 2007: Przewodnik do oznaczania zbiorowisk roślinnych Polski. Wydawnictwo naukowe PWN, Warszawa. 537 pp.

Meijer Drees, E. 1936: De bosvegetatie van de Achterhoek en enkele aangrenzende gebieden. Diss. Wageningen: 11-136.

Meusel, H., Jäger, E.J. \& Weinert, E. 1965: Vergleichende Chorologie der Zentraleuropäischen Flora. Gustav Fischer Verlag, Jena.

Moravec, J. 1973: Some notes on estimation of the basic homoteneitycoefficient of sets of phytosociological relevés. Folia Geobotanica et Phytotaxonomica 8(4): 429-434.

Morozova, O.V. 1999: The forests of the "Bryansk forest" Nature Reserve and the Nerusso-Desnyansky Polesie (syntaxonomic characteristic). Bryansk. 98 pp. [In Russian]

Mosyakin, S.L. \& Fedoronchuk, M.M. 1999: Vascular plants of Ukraine. A nomenclatural checklist. M.G. Kholodny Institute of Botany, Kyiv. 345 pp.

Mucina, L., Bültmann, H., Dierßen, K., Theurillat, J.-P., Raus, T., Čarni, A., Šumberová, K., Willner, W., Dengler, J., García, R.G., Chytrý, M., Hájek, M., Di Pietro, R., Iakushenko, D., Pallas, J., Daniëls, F.J.A., Bergmeier, E., Santos Guerra, A., Ermakov, N., Valachovič, M., Schaminée, J.H.J., Lysenko, T., Didukh, Y.P., Pignatti, S., Rodwell, J.S., Capelo, J., Weber, H.E., Solomeshch, A., Dimopoulos, P., Aguiar, C., Hennekens, S.M. \& Tichý, L. 2016: Vegetation of Europe: hierarchical floristic classification system of vascular plant, bryophyte, lichen, and algal communities. Applied Vegetation Science 19(S1): 3-264.

Oksanen, J., Blanchet, F.G., Friendly, M., Kindt, R., Legendre, P., McGlinn, D., Minchin, P.R., O'Hara, R.B., Simpson, G.L., Solymos, P., Stevens, M.H.H., Szoecs, E. \& Wagner, H. 2018: vegan: Community Ecology Package. R package version 2.4-6. URL: https:// CRAN.R-project.org/package=vegan [Accessed September 21, 2018]

Onyshchenko, V.A. 2006: Floristic classification of vegetation of Ukrainian Polissya. In Phytodiversity of the Ukrainian Polissia and its conservation, T. L. Andrienko [ed.], Phytosociocenter, Kyiv: 43-84. [In Ukrainian]

Onyshchenko, V.A. 2009: Forests of order Fagetalia sylvaticae in Ukraine. Alterpress, Kyiv. 212 pp.

Onyshchenko, V.A. 2011: Vegetation of Teremky locality (Holosyiv National Nature Park, Kyiv). Biolohichni systemy 3(1): 56-74. [In Ukrainian]

Onyshchenko, V.A. 2013a: Forest vegetation of Holosyiv Forest (Kyiv). Biolohichni systemy 5(1): 93-115. [In Ukrainian]

Onyshchenko, V.A. 2013b: Vegetation of Bychok forest (Holosyiv National Nature Park, Kyiv). Biolohichni systemy 5(3): 395-402. [In Ukrainian]
Padun, I.M. 1985a: Current state of vegetation of the Feofania Stow. Ukrainskyi Botanichnyi Zhurnal 42(2): 17-20. [In Ukrainian]

Padun, I.M. 1985b: Recreational changes in the plant cover of pine and oak-pine forests of Kiev Green Zone. Ukrainskyi Botanichnyi Zhurnal 42(3): 83-86. [In Ukrainian]

Panchenko, S.M. 2013: Forest vegetation of the Desna-Starogutsky National Nature Park. Universitetskaia Kniga, Sumy. 312 pp. [In Ukrainian]

Pogrebnyak, P.S. 1955: Basics of forest typology. Izdatelstvo AN USSR, Kyiv. 456 pp. [In Ukrainian]

Povarnitsyn, V.A. \& Shendrikov, N.I. 1957: Forest types of the Feofania experimental woodlands of the Academy of Sciences of Ukrainian SSR. Ukrainskyi Botanichnyi Zhurnal 14(1): 75-85. [In Ukrainian]

Rendón, E., Abundez, I., Arizmendi, A. \& Quiroz, E.M. 2011: Internal versus external cluster validation indexes. International Journal of Computers and Communications 5(1): 27-34.

Sádlo, J., Chytrý, M., Vítková, M., Petř́ik, P., Kolbek, J. \& Neuhäuslová, Z. 2013: Mezofilní a suché křoviny a akátiny (RhamnoPrunetea). Mesic and xeric scrub and Robinia groves. In Vegetace České republiky. 4. Lesní a křovinná vegetace. M. Chytrý [ed.], Academia, Praha: $74-156$.

Schubert, R., Herdam, H., Weinitschke, H. \& Frank, J. 2001: Prodromus der Pflanzengesellschaften Sachsen-Anhalts. Botanischer Verein Sachsen-Anhalt, Petersberg. 685 pp.

Semenishchenkov, Yu.A. 2018: Acidophilous broad-leaved forests of the Upper Dnieper basin: botanic-geographic features and problems of syntaxonomy. Biulleten Brianskogo Otdeleniia Russkogo Botanicheskogo Obshchestva 13(1): 52-69. [In Russian]

Shevchyk, V.L. \& Solomakha, V.A. 1996: Syntaxonomy of vegetation of the Kruglyk and Shelestiv islands of the Kaniv Nature Reserve. Ukrainian phytocoenological collection, Ser. A. 1: 12-27. [In Ukrainian]

Shevchyk, V.L., Solomakha, V.A. \& Voityuk, Yu.O. 1996: Syntaxonomy of vegetation and list of flora of the Kaniv Nature Reserve. Ukrainian phytocoenological collection, Ser. B. 4(1): 1-119. [In Ukrainian]

Šilc, U. \& Čarni, A. 2012: Conspectus of vegetation syntaxa in Slovenia. Hacquetia 11(1): 113-164.

Smahliuk, O.Y. 2016: Classification of communities of Robinietea Jurko ex Hadac et Sofron 1980 class of Lower Sula basin. Visnyk Cherkaskoho Universytetu. Seriia Biolohichni Nauky 2: 89-98. [In Ukrainian]

Solomakha, I.V., Vorobyov, E.O. \& Moysienko, I.I. 2015: Plant cover of forest and shrub vegetation of northern part of Black Sea region. Phytosociocentre, Kyiv. 387 pp. [In Ukrainian]

Solomakha, V., Smoliar, N. \& Smagliuk, O. 2016: Floristic classification of the floodplain alder, willow and poplar forests in the basin of the Lower Sula River (Ukraine). Visnyk Kyivskoho Natsionalnoho Universytetu imeni Tarasa Shevchenka. Biolohiia. 72(2): 33-44. [In Ukrainian]

Solomakha, V.A. 2008: Syntaxonomy of vegetation of Ukraine. $3^{\text {rd }}$ approximation. Phytosociocenter, Kyiv. 296 pp. [In Ukrainian] 
Soó, R. 1957: Systematische Übersicht der pannonischen Pflanzengesellschaften. Acta Botanica Academiae Scientiarum Hungarica 3: 317-373.

Tkach, V. 2001: Ukrainian floodplain forests. In The Floodplain Forests in Europe: Current Situation and Perspectives. E. Klimo, and H. Hager [eds.]. Brill, Leiden: 169-185.

Vítková, M. \& Kolbek, J. 2010: Vegetation classification and synecology of Bohemian Robinia pseudacacia stands in a Central European context. Phytocoenologia 40(2-3): 205-241.

Vojtková, J., Minarič, P. \& Kollár, J. 2014: Production-ecological analysis of herb layer in the softwood floodplain forests formed after the gabčíkovo waterwork construction and their characteristics.

Ekologia (Bratislava) 33(1): 9-15.
Vorobyov, Ye.O. 2014: New association of oak-pine forests of the alliance Quercion robori-petraeae Br.-Bl. 1932 in the Ukrainian Polissya. Biulleten Brianskogo Otdeleniia Russkogo Botanicheskogo Obshchestva 4(2): 27-41. [In Russian]

Weber, H.E., Moravec, J. \& Theurillat, J.-P. 2000: International Code of Phytosociological Nomenclature. 3rd edition. Journal of Vegetation Science 11(5): 739-768.

Westhoff, V. \& Van Der Maarel, E. 1978: The Braun-Blanquet approach. In Classification of plant communities, R. H. Whittaker [ed.], Dr. W. Junk, The Hague: 287-399.

Yakubenko, B.E. \& Grigora, I.M. 2007: Flora and vegetation of Holosyiv Forest and adjacent territories. In Ecology of "Holosyiv Forest" National Nature Park, Phoenix, Kyiv: 21-35. [In Ukrainian]

Vorobyov, Ye.O., Balashov, L.S. \& Solomakha, V.A. 1997:

Syntaxonomy of vegetation of the Polissya Nature Reserve. Ukrainskyi

Fitotsenotychnyi Zbirnyk, Ser. B. 8(1): 1-128. [In Ukrainian]

\section{Appendix}

Table 1: Synoptic table of studied forest vegetation. Constancies higher than $40 \%$ threshold marked in bold.

Tabela 1: Sinoptična tabela obravnavane gozdne vegetacije. Stalnost vrst večja od $40 \%$, je prikazana krepko.

\begin{tabular}{|c|c|c|c|c|c|c|c|c|c|c|c|c|c|c|c|c|c|c|}
\hline ID syntaxa & 1 & 2 & 3 & 4 & 5 & 6 & 7 & 8 & 9 & 10 & 11 & 12 & 13 & 14 & 15 & 16 & 17 & 18 \\
\hline Number of relevés & 39 & 22 & 26 & 7 & 21 & 9 & 53 & 64 & 11 & 21 & 55 & 30 & 17 & 36 & 33 & 115 & 35 & 41 \\
\hline \multicolumn{19}{|c|}{ Aristolochio clematitis-Populetum nigrae } \\
\hline Rumex thyrsiflorus & $74^{*}$ & . & 4 & . & . & . & . & . & . & . & . & . & . & . & 6 & . & 11 & 10 \\
\hline Galium rubioides & 54 & 5 & . & . & . & . & . & . & . & . & . & . & . & . & . & . & . & . \\
\hline Asparagus officinalis & 69 & . & . & . & . & . & . & . & . & . & . & . & 12 & . & . & . & 6 & 15 \\
\hline Sedum telephium & 64 & 5 & . & . & . & . & . & . & . & . & . & . & . & 3 & . & 3 & 6 & 15 \\
\hline Tanacetum vulgare & 46 & . & 4 & . & . & . & . & . & . & . & . & . & . & . & . & . & . & 12 \\
\hline Galium verum & 49 & . & . & . & . & . & . & . & . & . & . & . & . & . & . & . & 11 & 10 \\
\hline Carex praecox & 28 & . & . & . & . & . & . & . & . & . & . & . & . & . & . & . & . & . \\
\hline \multicolumn{19}{|c|}{$\begin{array}{l}\text { Galio aparines-Aceretum negundi var. } \\
\text { Aristolochia clematitis }\end{array}$} \\
\hline Aristolochia clematitis & 97 & 100 & . & . & . & . & . & . & . & . & . & . & . & . & . & . & . & . \\
\hline \multicolumn{19}{|c|}{ Galio aparines-Aceretum negundi } \\
\hline Galium aparine & 62 & 100 & 100 & . & 5 & 11 & 49 & 8 & . & . & 25 & 27 & 53 & 6 & 52 & 20 & 9 & 5 \\
\hline Myosotis sparsiflora & . & 23 & 35 & . & . & . & . & . & . & . & . & 7 & . & . & 3 & . & . & . \\
\hline Stellaria media & 28 & 36 & 50 & . & . & 11 & 2 & 2 & . & . & 2 & 7 & . & . & 15 & 2 & 6 & . \\
\hline \multicolumn{19}{|c|}{$\begin{array}{l}\text { Balloto nigrae-Robinietum pseudoacaciae } \\
\text { var. Acer tataricum }\end{array}$} \\
\hline Acer tataricum & 10 & 36 & 8 & 100 & 10 & . & 23 & 8 & . & 19 & 18 & 17 & 12 & 25 & 24 & 20 & 3 & 5 \\
\hline \multicolumn{19}{|c|}{ Balloto nigrae-Robinietum pseudoacaciae } \\
\hline Robinia pseudoacacia & 5 & 9 & 31 & 100 & 76 & . & 17 & 20 & 18 & 14 & 15 & 37 & 6 & 25 & 9 & 35 & 17 & 32 \\
\hline Ballota nigra & 8 & 27 & 31 & 71 & 48 & . & 6 & 6 & 9 & 10 & 5 & 20 & . & . & . & . & 9 & . \\
\hline \multicolumn{19}{|c|}{ Carici remotae-Alnetum glutinosae } \\
\hline Alnus glutinosa & . & . & . & . & . & 89 & . & . & . & . & . & . & . & . & . & . & . & . \\
\hline Carex remota & . & . & . & . & . & 89 & 2 & . & . & 5 & . & 3 & . & . & 3 & . & . & . \\
\hline Athyrium filix-femina & . & . & . & . & . & 44 & . & . & . & . & . & . & . & . & . & . & . & . \\
\hline Scirpus sylvaticus & . & . & . & . & . & 44 & . & . & . & . & . & . & . & . & . & . & . & . \\
\hline Lysimachia vulgaris & . & 9 & . & . & . & 44 & . & . & . & . & . & . & . & . & . & 1 & . & . \\
\hline Cardamine amara & . & . & . & . & . & 33 & . & . & . & . & . & . & . & . & . & . & . & . \\
\hline Chrysosplenium alternifolium & . & . & . & . & . & 22 & 2 & . & . & . & . & . & & & . & & & \\
\hline
\end{tabular}


\begin{tabular}{llllllllllllllllllll}
\hline ID syntaxa & 1 & 2 & 3 & 4 & 5 & 6 & 7 & 8 & 9 & 10 & 11 & 12 & 13 & 14 & 15 & 16 & 17 & 18
\end{tabular}

Galeobdoloni luteae-Carpinetum betuli var.

Acer campestre

Acer campestre

$18 . \quad . \quad 1008$

Galeobdoloni luteae-Carpinetum betuli var.

Prunus avium

Prunus avium

$5 \quad 18 \quad 8$

$4 \quad 100$

$\begin{array}{lll}5 & 7\end{array}$

$\begin{array}{lllll}22 & 3 & 9 & 3 & 10\end{array}$

Galeobdoloni luteae-Carpinetum betuli var.

Mercurialis perennis

Mercurialis perennis

$\begin{array}{llllll}11 & 21 \quad 100 & 38 & 24\end{array}$

Galeobdoloni luteae-Carpinetum betuli var.

Carex pilosa

Carex pilosa

Galeobdoloni luteae-Carpinetum betuli \&

d.s. ord. Fagetalia

Tilia cordata

Carpinus betulus

Asarum europaeum

Galeobdolon luteum

Aegopodium podagraria

Dryopteris filix-mas

Galium odoratum

Paris quadrifolia

Actaea spicata

Pulmonaria obscura

Stellaria holostea

Polygonatum multiflorum

25

$100 \quad 24 \quad 3 \quad 6$

Acer platanoides+Lapsana communis community

Lapsana communis

$\begin{array}{ccccccccccccccccccc}5 & 18 & 23 & . & 38 & \mathbf{4 4} & \mathbf{5 8} & \mathbf{5 5} & \mathbf{9 1} & \mathbf{8 6} & \mathbf{6 9} & 30 & 6 & 8 & 12 & 10 & . & . \\ 5 & 5 & 4 & . & 24 & \mathbf{4 4} & \mathbf{8 5} & \mathbf{6 7} & 18 & \mathbf{9 0} & \mathbf{8 4} & 33 & 24 & 8 & 27 & 24 & 3 & 2 \\ . & . & . & . & 10 & \mathbf{5 6} & \mathbf{6 6} & \mathbf{3 4} & \mathbf{8 2} & \mathbf{5 2} & \mathbf{6 7} & 10 & . & . & 9 & 2 & . & . \\ . & . & . & . & 10 & \mathbf{8 9} & \mathbf{4 2} & 11 & \mathbf{5 5} & \mathbf{7 1} & \mathbf{5 6} & 17 & . & . & 24 & 3 & . & . \\ . & . & 15 & . & 14 & \mathbf{8 9} & 36 & 14 & \mathbf{9 1} & \mathbf{5 7} & \mathbf{4 0} & 7 & . & . & 9 & . & . & . \\ 10 & 36 & . & 14 & 33 & 22 & 25 & 30 & \mathbf{7 3} & 33 & 35 & 3 & 35 & . & . & 6 & 3 & . \\ . & . & . & . & . & . & \mathbf{5 1} & \mathbf{5 6} & & 19 & \mathbf{4 4} & 7 & . & . & . & . & . & . \\ 3 & 5 & . & . & 5 & 33 & 9 & 33 & 9 & 10 & 13 & 7 & . & . & . & 3 & . & . \\ . & . & . & . & . & 11 & 2 & 20 & \mathbf{4 5} & 10 & 11 & 3 & . & . & . & 3 & . & . \\ . & . & . & . & . & 11 & \mathbf{6 6} & \mathbf{4 7} & 27 & 14 & \mathbf{7 6} & 10 & . & . & . & . & . & . \\ . & . & . & . & . & \mathbf{4 4} & \mathbf{7 5} & 11 & 9 & 24 & \mathbf{7 8} & 10 & . & . & 33 & 6 & 3 & . \\ . & 5 & 4 & 14 & 10 & 33 & \mathbf{7 0} & \mathbf{4 2} & \mathbf{4 5} & \mathbf{6 7} & \mathbf{7 5} & 7 & . & . & . & 6 & . & .\end{array}$

Dryopterido carthusianae-Pinetum sylvestris

var. Cardamine impatiens

Cardamine impatiens

55

Dryopterido carthusianae-Pinetum sylvestris var. Fragaria vesca

Berberis vulgaris

Fragaria vesca

$28 \quad 23$

Dryopterido carthusianae-Pinetum

sylvestris var. Carex ericetorum

Amelanchier spicata

Carex ericetorum

Luzula pilosa

Dryopterido carthusianae-Pinetum sylvestris

$\underline{\text { \& d.s. ord. Quercetalia roboris }}$

Convallaria majalis
Prunus serotina
Dryopteris carthusiana
Poa nemoralis
Pteridium aquilinum
Melica nutans
Galeopsis bifida
Brachypodium sylvaticum
Frangula alnus
Sambucus racemosa
Rubus idaeus

$\begin{array}{cccccccccccccccccc}5 & 18 & 8 & . & 5 & 22 & \mathbf{4 2} & 38 & . & 29 & \mathbf{5 1} & \mathbf{4 3} & \mathbf{9 4} & \mathbf{9 2} & \mathbf{9 7} & \mathbf{8 8} & \mathbf{6 3} & \mathbf{8 3} \\ 3 & 5 & 4 & . & . & 33 & 2 & 14 & . & . & . & 37 & \mathbf{8 8} & \mathbf{9 7} & \mathbf{8 8} & \mathbf{8 0} & \mathbf{8 3} & \mathbf{8 0} \\ 10 & 32 & 4 & . & 19 & \mathbf{7 8} & 9 & 12 & 36 & 38 & 22 & 33 & 18 & \mathbf{7 2} & \mathbf{7 0} & \mathbf{6 7} & \mathbf{4 0} & 12 \\ 13 & 32 & 4 & \mathbf{4 3} & 5 & 11 & 21 & 9 & . & 29 & 24 & 37 & \mathbf{7 1} & \mathbf{6 1} & 21 & 32 & 20 & 32 \\ . & . & . & . & . & . & 2 & 12 & . & . & . & 33 & \mathbf{7 6} & \mathbf{5 6} & \mathbf{7 3} & \mathbf{6 4} & \mathbf{4 3} & \mathbf{4 6} \\ . & . & . & . & . & . & 6 & 11 & . & . & 5 & 17 & \mathbf{7 1} & \mathbf{6 9} & 18 & 31 & 17 & \mathbf{5 4} \\ . & . & 4 & . & . & . & 2 & 5 & . & . & . & 17 & 12 & 19 & \mathbf{9 1} & 31 & \mathbf{6 9} & 15 \\ . & . & . & . & . & . & 6 & 11 & . & 5 & . & 23 & 18 & \mathbf{8 9} & 3 & \mathbf{8 3} & 11 & 22 \\ . & 5 & . & . & . & 11 & . & 3 & . & . & . & 3 & & 33 & 15 & 17 & \mathbf{4 0} & 27 \\ . & . & 4 & . & . & . & . & 6 & . & . & . & 17 & 6 & 31 & 18 & 24 & 31 & 5 \\ 15 & 23 & 19 & . & . & . & . & 2 & 9 & 5 & . & 17 & 12 & 19 & 21 & 24 & 17 & 2\end{array}$




\begin{tabular}{|c|c|c|c|c|c|c|c|c|c|c|c|c|c|c|c|c|c|c|}
\hline ID syntaxa & 1 & 2 & 3 & 4 & 5 & 6 & 7 & 8 & 9 & 10 & 11 & 12 & 13 & 14 & 15 & 16 & 17 & 18 \\
\hline \multicolumn{19}{|c|}{ Chamaecytiso zingeri-Pinetum sylvestris } \\
\hline Rumex acetosella & . & . & . & . & . & . & . & . & . & . & . & . & . & . & 12 & 4 & 63 & 5 \\
\hline Festuca ovina & 5 & . & . & . & . & . & . & . & . & . & . & . & . & . & 6 & 5 & 69 & 20 \\
\hline Calamagrostis epigejos & . & . & . & . & . & . & . & . & . & . & . & 7 & . & 14 & 3 & 1 & 74 & 44 \\
\hline Pilosella officinarum & 3 & . & . & . & . & . & . & . & . & . & . & . & 6 & 8 & . & 1 & 66 & 32 \\
\hline Avenella flexuosa & . & . & . & . & . & . & . & . & . & . & . & . & . & . & . & 1 & 26 & . \\
\hline Genista tinctoria & 8 & . & . & . & . & . & . & . & . & . & . & . & . & . & . & 1 & 26 & . \\
\hline Hypericum perforatum & 3 & . & . & . & . & . & . & . & . & . & 2 & 17 & 35 & 25 & 21 & 10 & 63 & 37 \\
\hline Veronica officinalis & . & . & . & . & . & . & . & . & 9 & . & . & 13 & 12 & 11 & 15 & 10 & 49 & 39 \\
\hline
\end{tabular}

Polygonato odorati-Quercetum roboris

\begin{tabular}{|c|c|c|c|c|c|c|c|c|c|c|c|c|c|c|c|c|c|c|}
\hline Peucedanum oreoselinum & . & . & . & . & . & . & . & . & . & $\cdot$ & . & . & . & 3 & . & . & 17 & 80 \\
\hline Campanula rotundifolia & . & . & . & . & . & . & . & . & . & . & . & . & . & . & . & . & 9 & 59 \\
\hline Melampyrum pratense & . & . & . & . & . & . & . & . & . & . & . & . & . & 3 & . & . & 23 & 68 \\
\hline Geranium sanguineum & . & . & . & . & . & . & . & . & . & . & . & . & . & 3 & . & . & 6 & 59 \\
\hline Hieracium umbellatum & . & . & . & . & . & . & . & . & . & . & . & . & . & 3 & . & 1 & 6 & 51 \\
\hline Cytisus ruthenicus & . & . & . & . & . & . & . & . & . & . & . & . & . & . & . & . & . & 41 \\
\hline Euphorbia cyparissias & . & . & . & . & . & . & . & . & . & . & . & . & 12 & 3 & . & . & . & 49 \\
\hline Polygonatum odoratum & . & . & 4 & . & . & . & . & 5 & . & 10 & . & . & 35 & 31 & 6 & 3 & 17 & 78 \\
\hline Rubus saxatilis & . & . & . & . & . & . & . & 8 & . & . & . & 10 & 6 & 17 & . & 19 & . & 49 \\
\hline Betonica officinalis & . & . & . & . & . & . & . & 3 & . & . & . & 3 & 6 & 25 & . & 3 & 9 & 44 \\
\hline \multicolumn{19}{|l|}{ Salicetea purpureae } \\
\hline Rubus caesius & 51 & 77 & 65 & 29 & 24 & 22 & 6 & 45 & 9 & 5 & 13 & 27 & 35 & 69 & 52 & 60 & 43 & 27 \\
\hline Festuca gigantea & 10 & 27 & 23 & . & . & 22 & 2 & 9 & . & . & 2 & 43 & 12 & 39 & 42 & 35 & . & 12 \\
\hline Humulus lupulus & 21 & 14 & 4 & 43 & 14 & . & . & 8 & . & . & 2 & 13 & . & 22 & 12 & 32 & 17 & 5 \\
\hline Stachys sylvatica & 5 & 18 & 23 & 14 & 5 & 22 & 23 & 9 & 27 & 19 & 22 & 3 & . & . & . & 1 & . & . \\
\hline Populus nigra & 54 & 82 & 38 & . & . & 11 & 2 & . & . & . & 2 & . & . & . & . & . & . & . \\
\hline Silene baccifera & 18 & 27 & . & . & . & . & . & 11 & . & . & . & 13 & 18 & 28 & 3 & 33 & 11 & 5 \\
\hline Populus alba & 26 & 32 & 23 & . & . & . & 6 & 6 & . & 14 & 5 & 3 & . & . & . & 1 & . & . \\
\hline Amorpha fruticosa & 28 & 18 & . & . & . & . & . & . & . & . & . & . & . & 3 & . & 3 & 9 & 5 \\
\hline Populus tremula & 5 & 14 & 8 & . & . & . & 6 & 3 & . & 5 & 4 & 10 & . & . & . & 2 & 3 & . \\
\hline Salix alba & 18 & 18 & . & . & . & . & 4 & 3 & 9 & . & 5 & . & . & . & . & . & . & . \\
\hline \multicolumn{19}{|l|}{ Robinietea } \\
\hline Impatiens parviflora & 28 & 59 & 69 & 14 & 100 & 100 & 64 & 94 & 91 & 90 & 64 & 87 & 88 & 100 & 97 & 95 & 54 & 34 \\
\hline Chelidonium majus & 23 & 18 & 54 & 100 & 86 & 22 & 28 & 30 & . & 14 & 35 & 80 & 41 & 44 & 55 & 65 & 37 & 32 \\
\hline Geranium robertianum & 38 & 55 & 23 & 14 & 14 & 11 & 38 & 53 & 64 & 29 & 36 & 70 & 53 & 67 & 73 & 69 & 31 & 41 \\
\hline Acer negundo & 44 & 77 & 88 & 86 & 81 & . & 9 & 41 & 18 & 14 & 20 & 40 & 41 & 78 & 21 & 57 & 9 & 34 \\
\hline Parthenocissus quinquefolia & 33 & 77 & 96 & 29 & 48 & . & 13 & 11 & 27 & 24 & 11 & 37 & 47 & 28 & 27 & 23 & 9 & 5 \\
\hline Erigeron annuus & 56 & 41 & 27 & 71 & 10 & 11 & 8 & 11 & 9 & 10 & 16 & 40 & 29 & 11 & 18 & 9 & 37 & 29 \\
\hline Oxalis dillenii & 8 & . & . & . & 14 & 11 & 6 & 6 & 9 & . & 4 & 27 & 24 & . & . & 5 & 9 & 2 \\
\hline Quercus rubra & 31 & 32 & 15 & . & 10 & 11 & 4 & 2 & . & . & 4 & 3 & . & . & 6 & 1 & 11 & . \\
\hline Acer saccharinum & 8 & 5 & 19 & 29 & 14 & . & 2 & . & 9 & . & . & . & . & 3 & . & 1 & . & 2 \\
\hline Acer pseudoplatanus & . & . & 4 & . & 24 & . & 2 & 3 & 9 & 14 & 4 & 3 & . & . & . & . & . & . \\
\hline \multicolumn{19}{|l|}{ Carpino-Fagetea } \\
\hline Quercus robur & 38 & 9 & 12 & . & 29 & 44 & 74 & 91 & 73 & 76 & 75 & 83 & 94 & 89 & 100 & 86 & 89 & 80 \\
\hline Acer platanoides & 18 & 45 & 58 & 86 & 86 & 33 & 94 & 78 & 64 & 76 & 64 & 70 & 35 & 33 & 27 & 44 & 17 & 20 \\
\hline Ulmus laevis & 62 & 86 & 85 & 86 & 48 & . & 36 & 11 & 18 & 10 & 24 & 37 & 47 & 42 & 45 & 50 & 14 & 17 \\
\hline Euonymus europaeus & 3 & 18 & 12 & 86 & 86 & 11 & 68 & 73 & 36 & 33 & 67 & 43 & 24 & 33 & 12 & 45 & 9 & 22 \\
\hline Euonymus verrucosus & . & . & . & . & 19 & . & 53 & 36 & 45 & 67 & 55 & 23 & 65 & 78 & 39 & 47 & 31 & 29 \\
\hline Corylus avellana & . & . & 4 & 29 & 24 & 33 & 17 & 59 & 73 & 14 & 42 & 40 & 12 & 17 & 45 & 48 & 34 & 7 \\
\hline Prunus padus & 8 & 27 & 12 & 14 & 10 & 67 & 6 & 22 & 27 & 10 & 5 & 30 & 6 & 17 & 61 & 37 & 29 & 2 \\
\hline Crataegus monogyna & 28 & 41 & 15 & 29 & 5 & . & 32 & 45 & . & 19 & 22 & 13 & 53 & 31 & 18 & 21 & 6 & 12 \\
\hline Fraxinus excelsior & 33 & 50 & 23 & 14 & 29 & 11 & 57 & 19 & 9 & 38 & 38 & 7 & . & 3 & . & 2 & 3 & . \\
\hline
\end{tabular}




\begin{tabular}{|c|c|c|c|c|c|c|c|c|c|c|c|c|c|c|c|c|c|c|}
\hline ID syntaxa & 1 & 2 & 3 & 4 & 5 & 6 & 7 & 8 & 9 & 10 & 11 & 12 & 13 & 14 & 15 & 16 & 17 & 18 \\
\hline Cornus sanguinea & 49 & 77 & 69 & . & 29 & 11 & 8 & 39 & 18 & 10 & 11 & 10 & . & 3 & . & . & . & . \\
\hline Ulmus glabra & . & . & . & . & 14 & 11 & 42 & 61 & 36 & 19 & 29 & 30 & . & 6 & 3 & 12 & . & 2 \\
\hline Viola mirabilis & . & 5 & . & . & . & 11 & 21 & 28 & 9 & 10 & 31 & 10 & 6 & 8 & 6 & 10 & 9 & . \\
\hline Milium effusum & . & . & 4 & . & . & 44 & 4 & 3 & . & 5 & 2 & 17 & 6 & 14 & 33 & 24 & 11 & 2 \\
\hline Pyrus communis & . & 14 & 15 & . & . & . & 17 & 2 & 9 & 5 & 5 & 3 & 18 & 17 & 6 & 10 & 6 & 20 \\
\hline Circaea lutetiana & . & . & . & . & . & 22 & 4 & 30 & 27 & 14 & 11 & 3 & . & 6 & . & 14 & . & . \\
\hline Malus sylvestris & 5 & 5 & 8 & . & 5 & . & . & 11 & 9 & . & 7 & 3 & 12 & 3 & 24 & 4 & 3 & 5 \\
\hline Anemone ranunculoides & . & . & . & . & . & . & 49 & . & . & . & 33 & . & . & . & . & . & . & . \\
\hline
\end{tabular}

\section{Vaccinio-Piceetea}

Pinus sylvestris $\quad \begin{array}{lllllllllllllllllllllll} & 51 & 9 & 4 & . & 5 & . & 4 & 20 & . & . & 2 & 57 & 100 & 100 & 100 & 99 & 100 & 100\end{array}$

Sorbus aucuparia

$\begin{array}{llllllllllllllllll}18 & 41 & 8 & . & 10 & 22 & 6 & 19 & . & 19 & 9 & 10 & 29 & 25 & 3 & 10 & 9 & 46\end{array}$

Maianthemum bifolium

Vaccinium myrtillus

Epilobietea angustifolii

\begin{tabular}{|c|c|c|c|c|c|c|c|c|c|c|c|c|c|c|c|c|c|c|}
\hline Geum urbanum & 56 & 73 & 92 & 100 & 86 & 89 & 62 & 89 & 82 & 38 & 58 & 73 & 76 & 56 & 39 & 43 & 3 & 15 \\
\hline Urtica dioica & 8 & 50 & 46 & 86 & 81 & 44 & 45 & 72 & 91 & 33 & 58 & 97 & 88 & 56 & 67 & 78 & 26 & 17 \\
\hline Sambucus nigra & 5 & 14 & 46 & 86 & 100 & 44 & 51 & 77 & 91 & 76 & 73 & 57 & 59 & 31 & 6 & 50 & 11 & 10 \\
\hline Alliaria petiolata & 13 & 59 & 85 & 100 & 48 & 11 & 57 & 20 & 18 & 14 & 24 & 47 & 18 & 28 & 33 & 39 & 6 & 5 \\
\hline Viola odorata & 15 & 50 & 69 & 71 & 62 & 22 & 53 & 33 & 18 & 38 & 55 & 17 & 6 & 3 & 3 & 1 & 3 & 2 \\
\hline Moehringia trinervia & 26 & 36 & 8 & 14 & . & 11 & 6 & 11 & . & 14 & 11 & 23 & 29 & 50 & 88 & 57 & 43 & 12 \\
\hline Glechoma hederacea & 28 & 45 & 31 & . & 10 & 11 & 21 & 19 & 27 & 5 & 13 & 53 & 24 & 25 & 61 & 20 & 11 & 2 \\
\hline Fallopia dumetorum & 26 & 32 & 4 & . & 29 & 22 & 11 & 19 & . & 5 & 11 & 27 & 12 & 50 & 9 & 42 & 9 & 27 \\
\hline Lactuca muralis & 3 & 5 & . & . & 10 & 33 & 2 & 16 & 27 & 38 & 11 & 30 & 59 & 22 & 18 & 19 & 11 & 20 \\
\hline Chaerophyllum temulum & 5 & 41 & 46 & 71 & 19 & . & 38 & 16 & 9 & 5 & 18 & 23 & . & . & . & 2 & . & . \\
\hline Torilis japonica & 36 & 23 & . & . & . & . & . & 19 & . & . & 5 & 27 & 12 & 17 & 15 & 4 & . & 7 \\
\hline Scrophularia nodosa & 8 & 9 & . & . & . & 11 & 15 & 6 & . & 10 & 7 & 33 & . & . & 3 & 2 & . & . \\
\hline \multicolumn{19}{|l|}{ Koelerio-Corynephoretea } \\
\hline Potentilla argentea & 13 & . & . & . & . & . & . & . & . & . & . & 3 & . & . & 3 & . & 3 & 5 \\
\hline Bromus inermis & 15 & . & . & . & . & . & . & . & . & . & . & 3 & . & . & 3 & . & . & . \\
\hline Koeleria glauca & 18 & . & . & . & . & . & . & . & . & . & . & . & . & . & . & . & . & . \\
\hline Myosotis stricta & 15 & . & . & . & . & . & . & . & . & . & . & . & . & . & . & . & . & . \\
\hline Artemisia marschalliana & 8 & . & . & . & . & . & . & . & . & . & . & . & . & . & . & . & . & . \\
\hline \multicolumn{19}{|l|}{ Molinio-Arrhenathretea } \\
\hline Lysimachia nummularia & 59 & 91 & 35 & . & . & 11 & 4 & 33 & 9 & . & 4 & 7 & 6 & . & . & 3 & . & . \\
\hline Poa pratensis & 74 & 27 & 12 & . & . & . & . & 2 & . & . & . & . & 6 & 8 & 33 & 12 & 40 & 37 \\
\hline Dactylis glomerata & 38 & 36 & 15 & . & 5 & 22 & . & 5 & . & 5 & 5 & 23 & 18 & 8 & 6 & 1 & 9 & 24 \\
\hline Carex hirta & 41 & 23 & . & . & . & . & . & . & . & . & . & 13 & 6 & 8 & 3 & 8 & 20 & 17 \\
\hline Equisetum pratense & 49 & 45 & 8 & . & . & 22 & 2 & . & . & . & 2 & 3 & . & . & . & . & . & . \\
\hline Achillea submillefolium & 21 & 5 & . & . & . & . & . & . & . & . & . & 17 & . & 3 & 3 & . & 6 & 22 \\
\hline Alopecurus pratensis & 54 & 5 & 4 & . & . & . & . & . & . & . & . & . & . & . & . & . & . & $\cdot$ \\
\hline Agrostis capillaris & 3 & . & . & . & . & . & . & . & . & . & . & 3 & . & 3 & 6 & . & 6 & 37 \\
\hline Elymus repens & 8 & . & 8 & . & . & . & . & . & . & . & . & 13 & . & . & . & . & 11 & 5 \\
\hline Stellaria graminea & 31 & . & . & . & . & . & . & . & . & . & . & . & . & . & 3 & . & 9 & . \\
\hline Ranunculus polyanthemos & 31 & 5 & . & . & . & . & . & . & . & . & . & . & . & . & . & . & $\cdot$ & . \\
\hline Agrostis gigantea & . & . & . & . & . & . & . & . & . & . & . & 3 & 6 & . & . & 1 & 20 & 2 \\
\hline Rhinanthus vernalis & 23 & . & . & . & . & . & . & . & . & . & . & . & . & . & . & . & . & . \\
\hline Festuca pratensis & 15 & . & . & . & . & . & . & . & . & . & . & . & . & . & . & . & . & . \\
\hline Plantago lanceolata & 10 & . & . & . & . & . & . & . & . & . & . & . & . & . & . & . & . & . \\
\hline \multicolumn{19}{|l|}{ Trifolio-Geranietea } \\
\hline Veronica chamaedrys & 36 & 27 & 31 & . & . & . & 15 & 5 & . & 5 & 2 & 17 & 53 & 17 & 42 & 15 & 31 & 34 \\
\hline Clinopodium vulgare & . & . & . & . & . & . & . & 2 & . & . & . & 10 & 12 & 44 & 12 & 10 & 9 & 39 \\
\hline Vincetoxicum hirundinaria & 13 & . & . & . & . & . & 6 & 2 & . & . & . & . & 24 & . & . & . & 17 & 29 \\
\hline
\end{tabular}




\begin{tabular}{|c|c|c|c|c|c|c|c|c|c|c|c|c|c|c|c|c|c|c|}
\hline ID syntaxa & 1 & 2 & 3 & 4 & 5 & 6 & 7 & 8 & 9 & 10 & 11 & 12 & 13 & 14 & 15 & 16 & 17 & 18 \\
\hline Silene nutans & . & . & . & . & . & . & . & . & . & . & . & . & 18 & . & . & 1 & 26 & 12 \\
\hline Eryngium planum & 38 & 5 & . & . & . & . & . & . & . & . & . & . & . & . & . & . & . & . \\
\hline Anthericum ramosum & . & . & . & . & . & . & . & . & . & . & . & . & . & 3 & . & . & 9 & 22 \\
\hline Trifolium montanum & 33 & . & . & . & . & . & . & . & . & . & . & . & . & . & . & . & . & . \\
\hline Filipendula vulgaris & 28 & . & . & . & . & . & . & . & . & . & . & . & . & . & . & . & . & . \\
\hline \multicolumn{19}{|l|}{ Other species } \\
\hline Betula pendula & 44 & 9 & 8 & . & . & . & 4 & 17 & . & 5 & 4 & 17 & . & 6 & 6 & 17 & 14 & 17 \\
\hline Ligustrum vulgare & 44 & 50 & 8 & . & . & . & 21 & 2 & . & . & 2 & . & . & 3 & . & . & . & . \\
\hline Carex contigua & 8 & 23 & 4 & . & . & 11 & . & 3 & 9 & . & 2 & 10 & 18 & 14 & 6 & 10 & . & 5 \\
\hline Erigeron canadensis & 38 & 9 & 8 & 14 & . & . & 6 & . & . & . & 2 & 13 & . & 6 & . & 3 & 9 & 7 \\
\hline Ficaria verna & 3 & 9 & 27 & . & . & . & 32 & . & . & 5 & 24 & . & . & . & . & . & . & .. \\
\hline Taraxacum officinale & 31 & 23 & 4 & . & . & . & 8 & 2 & . & . & 2 & 10 & 6 & . & . & . & . & 2 \\
\hline Ptelea trifoliata & 5 & 5 & . & . & . & . & . & . & . & . & . & . & 29 & 14 & 6 & 9 & 11 & 7 \\
\hline Melandrium album & 5 & 27 & 15 & . & . & . & . & . & . & . & . & 10 & . & 3 & 6 & 1 & 6 & 5 \\
\hline Glechoma hirsuta & 3 & 5 & . & . & 24 & . & 9 & 2 & 9 & 14 & 7 & . & 6 & . & . & 1 & . & . \\
\hline Viburnum opulus & 5 & 14 & . & . & . & 11 & 8 & 23 & . & 5 & 2 & . & . & 3 & . & . & 3 & . \\
\hline Plantago major & 3 & 9 & 4 & . & . & 11 & 2 & 5 & 9 & . & . & 23 & . & . & . & . & . & . \\
\hline Oxalis acetosella & . & . & . & . & . & 33 & . & . & . & . & . & 7 & . & . & 21 & 5 & . & . \\
\hline Viola matutina & . & . & . & . & . & . & . & . & 9 & . & . & 3 & . & . & 6 & 3 & 34 & 2 \\
\hline Artemisia vulgaris & 18 & 9 & . & . & . & . & . & 3 & . & . & 2 & 20 & . & . & . & . & . & . \\
\hline Carex sylvatica & . & . & . & . & . & 22 & 4 & 5 & & 10 & 9 & . & . & . & . & . & . & . \\
\hline Solanum dulcamara & . & . & . & . & . & 33 & . & . & . & . & . & . & 6 & 3 & . & 2 & 3 & . \\
\hline Hemerocallis fulva & . & 5 & 42 & . & . & . & . & . & . & . & . & . & . & . & . & . & . & . \\
\hline Berteroa incana & 10 & 9 & . & . & . & . & . & . & . & . & . & . & . & . & . & 1 & 9 & 12 \\
\hline Bromus mollis & 8 & 5 & . & 14 & 10 & . & 2 & 2 & . & . & . & . & . & . & . & 1 & 3 & . \\
\hline Cystopteris fragilis & . & . & . & . & . & . & 23 & . & . & . & 18 & . & . & . & . & . & . & . \\
\hline Lysimachia europaea & . & . & . & . & . & 22 & . & . & . & . & . & . & . & . & 9 & 3 & 3 & . \\
\hline Hypochaeris radicata & 3 & . & . & . & . & . & . & . & . & . & . & . & . & . & . & . & 23 & 5 \\
\hline Juncus inflexus & . & . & . & . & . & 22 & . & . & . & . & . & . & . & . & 3 & 3 & . & 2 \\
\hline Ranunculus auricomus & 13 & . & 4 & . & . & . & . & . & . & . & . & . & . & . & . & . & . & . \\
\hline Clematis recta & . & . & . & . & . & . & . & 2 & . & . & . & . & . & 6 & 6 & 1 & . & . \\
\hline Artemisia absinthium & 18 & . & . & . & . & . & . & . & . & . & . & 7 & . & . & . & . & . & . \\
\hline Anthriscus cerefolium & 15 & 14 & 4 & . & . & . & . & . & . & . & . & . & . & . & . & . & . & . \\
\hline Chenopodium album & 13 & 5 & . & . & . & . & . & . & . & . & 2 & 13 & . & 6 & . & . & 9 & 5 \\
\hline Rosa canina & 10 & 9 & . & . & . & . & 2 & . & . & . & 4 & . & . & . & . & . & . & 2 \\
\hline Lactuca serriola & 10 & 5 & . & . & . & . & 2 & . & . & . & . & 3 & . & 3 & 6 & 1 & 9 & . \\
\hline Anthriscus sylvestris & . & 18 & . & . & . & . & 4 & 2 & . & . & . & 10 & 6 & 3 & . & 2 & . & 2 \\
\hline Bromus sterilis & 10 & 18 & 19 & . & . & . & . & . & . & . & . & . & . & . & . & . & . & . \\
\hline Aesculus hippocastanum & . & . & 4 & . & 14 & . & . & 2 & . & 10 & . & . & . & . & . & . & . & . \\
\hline Impatiens noli-tangere & . & . & . & . & . & 11 & . & . & . & . & . & . & . & . & 3 & 1 & . & . \\
\hline Caltha palustris & . & . & . & . & . & 11 & . & . & . & . & . & . & . & . & . & . & . & . \\
\hline Ranunculus repens & . & . & . & . & . & 11 & . & . & 9 & 5 & . & . & . & . & . & . & . & . \\
\hline Lamium purpureum & . & 9 & 8 & . & . & . & 13 & 2 & 9 & . & 9 & 3 & . & . & . & . & . & . \\
\hline Juglans regia & . & 5 & 8 & . & 10 & . & 8 & 9 & 18 & 10 & 5 & 3 & . & . & . & . & . & . \\
\hline Cardamine bulbifera & . & . & . & . & . & . & 8 & 2 & . & 10 & 4 & . & . & . & . & . & . & . \\
\hline Equisetum hyemale & . & . & . & . & . & . & . & 2 & 9 & 10 & 2 & . & . & . & . & . & . & . \\
\hline Lathyrus vernus & . & . & . & . & . & . & 4 & 6 & 9 & 10 & 13 & . & . & . & . & . & . & \\
\hline Scilla siberica & . & . & . & . & . & . & 11 & . & . & . & 13 & . & . & . & . & . & . & \\
\hline Vinca minor & . & . & . & . & 10 & . & . & 5 & . & 5 & 11 & . & . & . & . & . & . & . \\
\hline Rumex sylvestris & . & . & . & . & . & . & . & 2 & . & . & . & 10 & . & . & . & . & . & . \\
\hline Tussilago farfara & . & . & . & . & . & . & . & . & . & . & . & 13 & . & . & . & . & . & . \\
\hline Bidens frondosa & . & . & . & . & . & . & . & . & . & . & . & 10 & . & . & 3 & . & 3 & . \\
\hline Lamium maculatum & . & 5 & 4 & . & . & . & 6 & 2 & . & . & . & 13 & . & . & . & . & . & . \\
\hline
\end{tabular}




\begin{tabular}{|c|c|c|c|c|c|c|c|c|c|c|c|c|c|c|c|c|c|c|}
\hline ID syntaxa & 1 & 2 & 3 & 4 & 5 & 6 & 7 & 8 & 9 & 10 & 11 & 12 & 13 & 14 & 15 & 16 & 17 & 18 \\
\hline Lilium martagon & . & . & . & . & . & . & . & 5 & . & . & . & 7 & 12 & 11 & . & 8 & . & . \\
\hline Ajuga genevensis & . & . & . & . & . & . & 8 & . & . & 5 & 2 & . & 12 & . & . & 1 & 9 & 10 \\
\hline Carex leporina & . & . & . & . & . & . & . & . & . & . & . & 3 & 12 & 3 & 3 & 8 & 6 & 2 \\
\hline Vitis sylvestris & . & 18 & . & . & . & . & . & . & . & . & . & . & 18 & . & . & 1 & . & . \\
\hline Elymus caninus & . & . & . & . & . & . & . & 3 & . & . & . & 7 & 6 & 17 & . & 5 & 6 & . \\
\hline Cruciata glabra & . & . & . & . & . & . & 4 & 2 & . & . & . & 3 & 6 & 11 & 6 & 1 & 3 & 2 \\
\hline Turritis glabra & . & . & . & . & . & . & . & . & . & . & . & 3 & . & . & 3 & 1 & 17 & 10 \\
\hline Sedum purpureum & . & 5 & . & . & . & . & . & . & . & . & . & . & . & . & 3 & . & 17 & . \\
\hline Cerastium holosteoides & 5 & . & . & . & . & . & . & . & . & . & . & . & . & . & 9 & . & 14 & . \\
\hline Luzula multiflora & . & . & . & . & . & . & . & . & . & . & . & . & 6 & 11 & . & 3 & 17 & . \\
\hline Capsella bursa-pastoris & 8 & . & . & . & . & . & . & . & . & . & . & . & 6 & . & 3 & . & 14 & . \\
\hline Digitalis grandiflora & . & . & . & . & . & . & . & . & . & . & . & . & . & . & . & . & 11 & . \\
\hline Festuca rubra & 10 & . & . & . & . & . & . & . & . & . & . & . & . & . & 6 & 3 & 11 & 2 \\
\hline Polygonum aviculare & 5 & . & . & . & . & . & . & . & . & . & 2 & 3 & . & . & 6 & 1 & 11 & . \\
\hline Ambrosia artemisiifolia & . & . & . & . & . & . & . & . & . & . & . & 3 & 6 & . & . & . & 11 & 2 \\
\hline Silene vulgaris & . & . & . & . & . & . & . & . & . & . & . & . & 6 & . & . & 1 & 3 & 12 \\
\hline Saponaria officinalis & . & 5 & . & . & . & . & . & . & . & . & . & 3 & . & 6 & . & . & 3 & 12 \\
\hline Viola canina & . & . & . & . & . & . & . & . & . & . & . & . & . & 3 & . & . & . & 12 \\
\hline Veronica spicata & . & . & . & . & . & . & . & . & . & . & . & . & . & . & . & . & . & 12 \\
\hline Teucrium chamaedrys & . & . & . & . & . & . & . & . & . & . & . & . & . & . & . & . & . & 12 \\
\hline Rubus nessensis & . & . & . & . & . & . & . & 2 & . & . & . & . & . & 14 & . & 4 & 3 & 15 \\
\hline Allium oleraceum & . & . & . & . & . & . & . & 3 & . & . & . & . & . & 3 & . & 1 & . & 10 \\
\hline Melampyrum nemorosum & . & . & . & . & . & . & . & 2 & . & . & . & 3 & . & 3 & . & . & . & 10 \\
\hline Physocarpus opulifolius & 3 & . & . & . & . & . & . & . & . & . & . & . & . & . & . & 1 & . & 10 \\
\hline Potentilla alba & . & & . &. & . & . & . & . & . & . & . & . & . & . & . & . & . & 10 \\
\hline
\end{tabular}

Rare species: Agrimonia eupatoria (01, 03, 12, 14, 18); Allium angulosum (01); Anthoxanthum odoratum (17, 18); Arctium lappa (01, 07, 12); Arctium tomentosum (12); Arenaria uralensis (01, 03); Asclepias syriaca (18); Asperugo procumbens (01); Astragalus glycyphyllos (12, 14, 16); Berberis aquifolium (07); Betula pubescens (08); Bromus tectorum (01, 03); Calamagrostis arundinacea (18); Calluna vulgaris (17, 18); Campanula patula (12); Campanula trachelium (08, 11); Caragana arborescens (10, 17); Cardamine quinquefolia (10); Carex colchica (07); Carex digitata (10, 11); Carex michelii (07, 11); Carex pallescens (08, 17); Celtis occidentalis (13, 17, 18); Chamerion angustifolium (12); Cichorium intybus (12); Cirsium oleraceum (07); Cirsium setosum (12); Daucus carota (12); Duchesnea indica (08, 10); Echinochloa crus-galli (12); Echium vulgare (17, 18); Epilobium tetragonum (12); Equisetum arvense (01, 02); Gagea lutea (11); Galinsoga parviflora (12, 15); Geranium pratense (12); Geranium pusillum (01, 03, 12); Gleditsia triacanthos (01); Grossularia reclinata (03, 05); Hedera helix (05); Helichrysum arenarium (18); Heracleum sibiricum (16); Heracleum sphondylium (05); Hieracium piloselloides (17); Hierochloe odorata (17); Iris pseudacorus (02); Juglans mandshurica (09); Juncus effusus (12); Knautia arvensis (13); Lathraea squamaria (07); Lathyrus niger (07, 08, 11, 12, 16); Leonurus quinquelobatus (02, 03, 07, 11, 12, 15); Lolium perenne (12, 17); Lonicera caprifolium (07, 10, 11); Lycopus europaeus (18); Medicago falcata (12); Morus nigra (03, 08, 13, 17); Neottia nidusavis (08, 11, 14); Origanum vulgare (12); Pastinaca sylvestris (12); Phleum phleoides (18); Poa annua (17); Poa bulbosa (01, 02); Poa palustris (01, 02, 16); Polygonum persicaria (12, 15, 16, 17); Primula veris (07); Prunella vulgaris (12, 15, 18); Prunus spinosa (18); Ranunculus acris (08, 12); Reynoutria japonica (03, 09, 15); Rhodococcum vitis-idaea (16); Ribes aureum (08); Rumex confertus (12); Sanicula europaea (08); Scutellaria altissima (11); Sedum sexangulare (01); Sempervivum ruthenicum (18); Solidago canadensis (08, 10 , 11, 12, 13); Spergula arvensis (17); Stachys palustris (08, 12); Thlaspi arvense (12); Thymus serpyllum (18); Tragopogon orientalis (17); Trifolium alpestre (18); Trifolium arvense (18); Trifolium medium (12); Trifolium pratense (01, 07, 12); Ulmus minor (11); Verbascum lychnitis (17); Veronica arvensis (01, 02, 03, 15); Veronica verna (01); Vicia sepium (11, 12); Viola hirta (16); Viscaria vulgaris (16, 17); Xanthium strumarium (12). 